NBER WORKING PAPER SERIES

\title{
GLOBALIZATION, TRADE \& WAGES: WHAT DOES HISTORY TELL US ABOUT CHINA?
}

\author{
Kris James Mitchener \\ Se Yan \\ Working Paper 15679 \\ http://www.nber.org/papers/w15679
NATIONAL BUREAU OF ECONOMIC RESEARCH
1050 Massachusetts Avenue
Cambridge, MA 02138
January 2010

We thank John Brown, Carolyn Evans, John Ifcher, Wolfgang Keller, Naomi Lamoreaux, Kevin O'Rourke, Larry Qiu, Alan Taylor, and Bin Xu as well as seminar and conference participants at UC Santa Cruz, Carlos III, IMT Lucca, and the ASSA and CNEH annual meetings for helpful comments and suggestions. Mitchener acknowledges the financial support of the Global Fellows Program, International Institute, UCLA and the Hoover Institution, Stanford University. Yan acknowledges the financial support of UCLA Center for Economic History and China National Social Science Foundation (Grant 09CJL009). The views expressed herein are those of the authors and do not necessarily reflect the views of the National Bureau of Economic Research.

NBER working papers are circulated for discussion and comment purposes. They have not been peerreviewed or been subject to the review by the NBER Board of Directors that accompanies official NBER publications.

(C) 2010 by Kris James Mitchener and Se Yan. All rights reserved. Short sections of text, not to exceed two paragraphs, may be quoted without explicit permission provided that full credit, including $₫$ notice, is given to the source. 
Globalization, Trade \& Wages: What Does History tell us about China?

Kris James Mitchener and Se Yan

NBER Working Paper No. 15679

January 2010, Revised November 2012

JEL No. F15,F33,N25,N75

\begin{abstract}
$\underline{\text { ABSTRACT }}$
Chinese imports and exports grew rapidly during the first three decades of the twentieth century as China opened up to global trade. Using a new data set on the factor-intensity of traded goods at the industry level, we show that Chinese exports became more unskilled-intensive and imports became more skill-intensive during these three decades. The exogenous shock of World War I dramatically raised the price of Chinese exports and increased the demand for these goods overseas and for unskilled workers producing these goods in China. When the war ended, trade costs declined, leading to a rise in China's terms of trade and further growth in China's export sector. Difference-in-differences regression estimates show that World War I boosted exports in China and did so substantially more for unskilled industries than skilled industries. We show that the observed decline in the skill premium in China is consistent with China's changing terms of trade. The skill-unskilled wage ratio flattened out during the 1910 s and then fell by eight percent during the 1920s. We simulate the effects of World War I using a dynamic, general equilibrium factor-endowments model of trade, and demonstrate that an exogenous shock to the price of traded goods can produce a decline in the skill premium similar to what China experienced in the 1920 s.
\end{abstract}

Kris James Mitchener

Department of Economics

Leavey School of Business

Santa Clara University

Santa Clara, CA 95053

and NBER

kmitchener@scu.edu

Se Yan

Department of Applied Economics

Guanghua School of Management

Peking University

Beijing 100871, China

seyan@gsm.pku.edu.cn 


\section{Globalization, Trade, and Wages: What Does History tell us about China?}

One of the most contentious issues with respect to the global growth in trade is its effects on wages. Much of the debate has focused on how the expansion in trade between developing and developed countries affects the wages in the United States and Europe. The logic of trade theories such as the Heckscher-Ohlin-Vanek (HOV) model and Stolper-Samuelson (SS) suggest that an expansion of trade will raise the wages of skilled workers and lower those of unskilled workers in developed countries if they are relatively well endowed with skilled labor. This has led some commentators to link the growing wage inequality within the U.S. to trade with the rest of world; even more specifically, some have suggested that as U.S. trade with China grows, wages for unskilled workers in the U.S. will fall in response.

An equally interesting question is how the global trade boom has altered wages in developing countries. For example, factor endowments also predict that the skill premium should be falling in rapidly developing countries like China where the stock of unskilled workers is large relative to developing countries. Using city-level data, Wei and Wu (2001) find evidence that inequality has fallen within China, and that the decline in rural-urban inequality have been most pronounced in areas that increased their openness (trade-GDP ratios). On the other hand, other empirical studies suggest that globalization has likely increased inequality in developing countries in the last three decades, although these findings depend on country-specific and timespecific factors. ${ }^{1}$ For example, Wan, Lu, and Chen (2007) present evidence that increased FDI and trade have widened inequality within China more recently.

Determining the impact of the current trade boom on wages in developing and developed countries is complicated since trade has become more complex than what factor endowments models (whose origins are at least 90 years old) typically describe. Intra-industry trade, outsourcing, offshoring, and multinationals complicate the testing of their theoretical predictions. More generally, confounding influences make the task of causal inference extremely challenging for studies examining current trade flows. For example, in thinking about the impact of expanding trade on the wage premium in developed countries today, empirical researchers may

\footnotetext{
${ }^{1}$ For a survey, see Goldberg and Pacvcnik (2007). For articles on the effects of trade on skill premia in specific countries see, for example, Robbins (1996), Beyer, Rojas, and Vergara (1999), Gasparini (2003), Hanson (2004), and Robertson (2000, 2004).
} 
also need to account for declining union power, falling minimum wages, increased rates of immigration of unskilled workers, and greater skill-biased technological change. Similarly, analyses that focus on the impact of trade on wages in developing countries, like China, also face an array of challenging empirical issues that make identification difficult, including assessing the impacts of technological change, foreign direct investment, and state intervention on factor prices.

A number of scholars have suggested that the late nineteenth and early twentieth centuries may be better periods for testing the empirical predictions of factor endowments models. Estevadeordal and Taylor (2002) argue that low barriers to trade (especially in simple manufactured goods and agriculture), more skewed factor endowments, less trade in differentiated products and services, and minimal intra-industry trade are some characteristics of the first era of globalization that may make it a good laboratory for testing this class of models. O’Rourke and Williamson (1994) and O’Rourke, Taylor and Williamson (1996) have provided empirical evidence of factor price convergence and other predictions of these models during the great expansion of trade in the late nineteenth century.

In this paper, we use the lens of history to better understand how a rapid expansion in trade affects the skill premium for a developing country. In particular, we ask how the skill premium in China responded to an earlier era of globalization and explosive growth in trade. We assemble new data on Chinese trade and wages for the period from 1903 to 1928 and use the exogenous shock of World War I to shed light on this question.

During the first three decades of the twentieth century, China experienced a tremendous growth in trade with the rest of the world. The nominal value of exports sextupled and imports rose roughly by the same amount (Figure 1). ${ }^{2}$ Although China had been forcibly opened to trade in the 1840s, the scale of trade was quite small until the Treaty of Shimonoseki was signed and an era of conflict with foreign powers concluded with Chinese supplication in the Boxer Uprising (1899-1901). The beginning of our sample period hence corresponds to a period of less

\footnotetext{
${ }^{2}$ It is conceivable that China's growth in trade during this period resulted from some other factor, such as being on the silver standard. However, staying on silver appears to have reduced bilateral trade during the first part of the 20th century because the world had moved to the gold standard. This move included China's most important trading partners, both in Asia (Japan) and internationally (Britain, Germany, the United States, and France). China had higher trade costs as a result of being on a monetary standard that was different from the rest of the world (Mitchener and Voth, 2011). It could have been the case that China received some benefit from falling silver prices relative to gold, but the silver-gold price ratio moves little during our sample period, and when it did change, the price of silver rose relative to gold. If this had any effect, it would have tended to reduce China's terms of trade,
} 
conflict with foreign powers and China's entry into the global trade boom of the late nineteenth and early twentieth centuries. Like the current period of globalization, China's economy dramatically opened up to world trade: total trade as a share of GDP almost tripled during our sample period, an increase that is roughly comparable what China has experienced since 1978. With respect to the effects that trade had on wages, the most important change may have occurred in response to World War I - an event that altered global trade patterns and had lasting effects on Chinese trade. We show that the price of Chinese exports rose, leading to a surge in the production of goods China sold overseas. Wages and employment for unskilled workers, which were utilized intensively in the production of Chinese exports, eventually rose in response to the export boom. Consistent with the movement in the terms of trade, this finding appears to hold most strongly once the war ended and temporarily high transport and insurance costs on imported goods caused the price of imports to decline relative to the price of exports.

We marshal new hand-collected archival data on the factor content of Chinese trade to show that China's export boom in the first three decades was characterized by a rapid expansion in the production and sale of unskilled-intensive products to the rest of the world. In the second decade of the twentieth century, China's growth in exports of unskilled-intensive manufactures, mining, and agricultural products received an additional boost in demand from World War I. Whereas the war disrupted trade in many other parts of the world, it caused an expansion in Chinese exports, creating new markets for Chinese goods that had previously been served by producers in belligerent countries.

Employing newly collected unit value data from historical Chinese trade statistics, we show that the prices of key exports rose rapidly in response to the exogenous shock of World War I and continued to rise even after hostilities ended. Exports continued their upward trajectory as China's products were integrated into the global trade network, and after wartime transport costs fell, Chinese terms of trade dramatically improved in the 1920s. Further, empirical estimates based on difference-in-differences regressions show that World War I boosted exports, and that it raised exports substantially more for unskilled industries than skilled industries in China. Since World War I is a plausibly exogenous shock to the Chinese economy, our difference-in-differences estimates suggest a causal relationship between the war and the export boom of China’s unskilled sectors. 
Using new data on wages for unskilled and skilled workers obtained from Chinese archives, we argue that the growth in Chinese trade and the boost it received from World War I largely account for the flattening out of the skill premium in the 1910s and the subsequent 8 percent fall in the skill premium between 1920 and 1928 (Figure 2). ${ }^{3}$ We develop a general equilibrium model of trade (based on factor endowments), extending the HOV framework to a dynamic context, and show how a price shock affects the skill premium. We then simulate the model and compare the results to the observed data on changes in the skill premium. We find that our model produces a similar decline in the skill premium once an exogenous terms-of-trade shock is taken into account. We further show that the skill premium would have declined even sooner had import costs not been temporarily inflated due to elevated insurance and shipping costs.

In the next section, we provide some historical background on the growth in Chinese trade during the first three decades of the twentieth century. Section III describes how we employ the theoretical predictions from factor endowments models to conduct a factor content analysis of Chinese trade. Section IV describes our new trade database assembled from the publications of the Chinese Maritime Customs Service and our methodology for estimating the factor content of trade. Section V assesses the relationship between factor content and export growth. It presents empirical evidence on changes in export prices and the overall Chinese terms of trade, provides empirical estimates of the effects of World War I and skill intensity on trade, and relates our trade data to changes in the skill premium in China during the first three decades of the twentieth century. Section VI presents a general equilibrium model of trade, simulates a price shock, and compares the results from the model to observed changes in the skill premium. The final section discusses the implications of our findings and concludes.

\footnotetext{
${ }^{3}$ As we state above, the trade-GDP ratio roughly triples during our sample period - comparable to the change observed since 1978. That said, this ratio starts from a very small base, which raises questions about how general our findings are for China as a whole. It should be noted that our wage data are largely drawn from coastal areas those most impacted by external trade. Hence, one would expect that the effects of trade on wages would be most pronounced in coastal provinces, and depending on the degree of labor market integration with the rest of China, they would carry over to the rest of the country. Although we cannot directly test the degree to which the effects carry over to inland areas, this narrower interpretation would be consistent with evidence on modern china. Using city-level data, Wei and Wu (2001) find evidence that inequality has fallen within China, and that the decline in rural-urban inequality have been most pronounced in areas that increased their openness (trade-GDP ratios). Moreover, as Leamer (1998) reminds us, prices are set on the margin in Stolper-Samuelson, implying it does not matter how big trade is relative to GDP or how important that sector is to GDP; rather, what matters is that an unskilled laborer in a particular industry is producing goods that an unskilled worker in another country is also producing, but the latter worker is earning a substantially different wage.
} 


\section{China's First Twentieth-Century Trade Boom}

The first three decades of the twentieth century mark the period when China's trade with the rest of the world expanded significantly. Until the 1840s, China was largely a closed, agrarian economy; however, pressure from Great Britain and other foreign powers led China to open its economy to international trade. The 1842 Treaty of Nanking permitted foreigners to trade with the Chinese in five ports and stipulated a general five percent ad valorem tariff on almost all goods leaving and entering China. Over the subsequent sixty years, China saw a gradual opening up of trade as China signed treaties with foreign powers and additional ports were allowed to transact with foreigners. ${ }^{4}$

China's defeat in the Sino-Japanese war in 1895 ushered in further changes to Chinese trade and production. The Treaty of Shimonoseki allowed Japanese businesses to invest directly in China and produce goods and services that could be sold abroad as well as within China. Soon after the treaty was signed, this privilege was extended to other foreign nations via most-favorednation agreements. Foreign capital financed railroad, telecommunications, and shipping enterprises and spurred industrialization.

By the early twentieth century, the number of cities open to trade had climbed to 48 cities. As ports opened up and foreigners were allowed to invest and trade, China transitioned from a closed to an open economy. With no notable trade policy restrictions in place, China then experienced a sustained growth in international trade (Figure 1). Cheng (1956) estimates that between 1900 and 1913 the total value of trade grew twice as much as it had between 1868 and 1900. In the first 13 years of the twentieth century, the value of foreign exports nearly tripled, imports almost quadrupled, and the annual growth rate of trade averaged 7.4 percent. China's trade growth was faster than the world average in the first three decades of the twentieth century: its share of world trade increased from 1.5 percent around 1898 to 3.44 percent by 1928 . By the early twentieth century, the Chinese economy was exploiting its comparative advantage in unskilled manufactures. Indicative of this growth was trade in cotton textiles, which became one of the fastest growing industries over the subsequent decades.

As we emphasize throughout this paper, World War I had transformative effects on the Chinese economy. It disrupted trade in other parts of the world and redirected it in the ways that 
directly benefited China, including a large increase in demand for its exports. Although China did not experience a dramatic acceleration in the growth rate of exports during World War I, this fact disguises several important effects the war had on Chinese exports and wages. First, while many countries experienced a contraction in trade during World War I (Glick and Taylor, 2001), China's growth in trade during the war period was superior to the average country. Imports were disrupted throughout World War I, but exports were only temporarily affected. After declining for one year, exports resumed their upward trajectory. Even during the war, they continued to grow at trend rather than below trend (Figure 1). In the ten years from 1917 to 1927, they grew at 7 percent annually. Just as important, the price of its exports began to rise during the war and continued an upward trajectory through the 1920s - even when import prices declined.

Second, the war redirected trade between other countries to China. For example, Chinese exports to countries like the United States and Japan increased rapidly. China's exports to the United States grew at an annual rate of 6\% before World War I, but boomed after the war started, growing at roughly $27 \%$ per year thereafter. Exports to Japan followed a similar pattern over this interval, growing at $5.8 \%$ per year in the prewar period to $17.4 \%$ per year after WWI started. Once it gained entry into these new markets, the Chinese were better placed to stay. It expanded production and further specialized according to comparative advantage. Growth in trade to these markets may have also been self reinforcing process, producing dynamic benefits similar to what Krugman (1987) has emphasized.

Third, most of China's top exports (coal, minerals and mineral products, raw cotton and cotton textiles, bristle, and edible oils) received a considerable boost from World War I. Importantly, demand from the rest of the world did not subside after the war ended (see Table 1). For example, trade records indicate that domestic yarn firms (cotton textiles) started to export in 1913, and by the mid 1920s, had largely displaced imports (Figure 3). Bristle (one of China's top 10 exports) was used to make brushes for machines, guns, and cannons; by 1930, China was supplying 90\% of the world's bristle (You, 1990). Edible oil, another top 10 export for China, received a considerable boost from World War I. After the outbreak of war, the oil-pressing industry in Europe switched to the production of military-related products, leaving a huge gap in demand for edible oil in these countries. China filled this gap by dramatically increasing its exports to some of the European belligerent countries. For example, exports to Britain increased

\footnotetext{
${ }^{4}$ During this period, the largest import commodities were opium, cotton textiles, and petroleum products (kerosene,
} 
by roughly 28\% between 1904 and 1908, and annual growth rates of Chinese exports to Britain remained high after the cessation of war, hovering at a rate of more than 10\% per year from 1918 to 1928. In a few countries, transport disruptions were so great that Chinese exports either declined or stopped (as in the case of Germany during the first years of the war). But even in these countries, Chinese exports grew impressively after the war ended. In France, they grew at 9.9\% per annum, and in Germany, they recovered dramatically, growing at 73\% per year from 1919 to 1928 . The value of China's exports to Germany amounted to nearly 5 million British Pounds in 1928, doubling their 1913 value. Overall, the aggregate data suggest that the war likely increased Chinese trade for two reasons: (1) it raised other countries' multilateral resistance (leading to some diversion to China) and lowered China's resistance (pure trade creation).

\section{Theoretical Framework}

To formulate testable predictions of the effects of this trade boom on wages and (in Section VI) simulate the effects of a price shock on Chinese trade, we draw on insights from factor endowments models of trade. The Heckscher-Ohlin-Vanek model predicts that when an economy that is relatively well endowed with unskilled labor opens up to foreign trade, it will specialize in producing unskilled labor intensive products for export. According to the StolperSamuelson theorem, an increase in the terms of trade will lead to an expansion in exports. Wages for unskilled workers will rise relative to those of skilled workers. Although HOV models and their related theorems often abstract from reality in their parsimony (two countries, two goods, two factors) and in their theoretical assumptions (constant returns to scale, perfect competition, identical production technologies, free mobility of goods, etc.), they are nevertheless useful for framing how trade based on comparative advantage affects factor prices within countries and for drawing attention to the winners and losers in trade. For example, policymakers have used the simple predictions of the $2 \times 2 \times 2$ version of the models and the Stolper-Samuelson theorem to explain how increased trade and globalization is impacting wages. They also have been used by economists to consider the extent to which trade is driving increased wage inequality in the U.S. and other developed countries (Leamer, 1988; Revenga, 1992; Lawrence and Slaughter, 1993;

gasoline, etc.). Major exports were tea and silk. 
Wood, 1995, 1998), and similarly, in predicting the consequences that China's expanding bilateral trade with the U.S. will have on U.S. wages (Krugman, 2008; Lawrence, 2008).

Despite its theoretical elegance, testing the predictions of the Stolper-Samuelson theorem is challenging. First, there are identification issues that make estimating the effects of trade on wages using modern data extremely challenging. Skill premiums today may be driven by a variety of factors that are difficult to disentangle, including technology, migration, and institutional changes in labor markets. ${ }^{5}$ In addition, researchers often restrict their attention to simple versions of factor content models so that they retain clearer theoretical predictions and avoid issues such as factor substitutability. Second, there is skepticism among some researchers that SS accurately describes the relationship between trade and wages. One strand of the empirical literature, which emphasizes the effects of tariff liberalization on wages, finds little support for it (Feliciano, 2001; Galiani and Sanguinetti, 2003; Goldberg and Pavcnik, 2004; Harrison and Hanson, 1999; Revenga 1997; and Robertson 2004). Many of these studies, however, provide only indirect tests based on an examination of relative wages before and after trade liberalization. It is also possible that researchers have found these results because protection initially occurs in sectors that use unskilled labor more intensively, such that trade liberalization in turn causes a decline in these sectors' wages and wage inequality to widen. ${ }^{6}$ Several studies using economy-wide data or disaggregated industry-level data compare relative prices and relative wages and find evidence in support of the operation of SS (Bhagwati 1991; Lawrence and Slaughter 1993; Feenstra and Hanson 1995; Sachs and Shatz 1994; Leamer 1998; Baldwin and Cain 1998). Slaughter (1998) concludes that empirical results appear to depend on the selection of the included industries and the decades under consideration.

Our analysis builds on the existing literature by offering empirical tests and model simulations based on a period that may be more suitable for testing SS. The model, which we use to simulate the Chinese economy of the early twentieth century, is a dynamic extension of a classic HOV model. A simple two-good, two-factor, two-country HOV model can be used to examine economies at snapshot, say before and after opening up, or it can provide a static, period-by-period analysis, but it cannot be used to simulate the long-run dynamic effects of

\footnotetext{
${ }^{5}$ For a review of factors driving skill premium today in developing countries, see Goldberg and Pavcnik (2007).

${ }^{6}$ Some recent studies, such as Galiani and Porto (2010), find that, after controlling for the structure of tariffs at the industry level, the average tariff in the economy is positively associated with the average skill premium over time and that trade liberalization can lead to a decline in the skill premium as predicted by the Heckscher-Ohlin model.
} 
changing terms of trade or foreign demand on factor prices. To simulate these dynamic effects, we follow a strand of the literature that combines trade models with neoclassical growth models so that we can analyze long-run effects of changing economic conditions on trade patterns and factor prices. (See, for example, Stigliz (1970), Mussa (1978) and Bond, Trask and Wang (2003)). Most dynamic models in this tradition are two-country systems that are unsuitable for simulating the changing factor prices of a "small' open-economy facing exogenous demand and price shocks. In section VI, we thus combine the insights of a classic HOV model with a neoclassical growth model adapted to the context of a single price-taking country, and use it to simulate the dynamic effects with real data on price shocks.

There are several reasons why factor endowments models and empirical estimates or simulations derived from them may be more appropriate in explaining the effect that trade has on wages in historical periods, including our study of China during the first three decades of the twentieth century. ${ }^{7}$ First, bulky standardized commodities, such as wheat and meat, and simple manufactures, like cotton goods, were the basis for the global growth in trade in the latenineteenth and early-twentieth centuries (Findlay and O'Rourke, 2003). Unlike today's trade, such standardized commodities were also less likely to be produced by value chains where production can be broken up into parts across borders (Krugman, 2008). In contrast to the differentiated trade in goods and services today, differences in factor endowments may be sufficient for explaining the movement of raw materials and simple manufactures across national boarders (i.e., it may be unnecessary to appeal to newer trade models emphasizing product differentiation or the within-industry effects, such as Melitz (2003)). Second, there were fewer tariff and non-tariff barriers to trade, especially with respect to agricultural goods and low-skilled manufactured goods - two important areas of export for China during our sample period (Estevadeordal and Taylor, 2002). ${ }^{8}$

Third, the effects of technological change operated differently on developing countries' skill premia, like China's, during the first global trade boom. In contrast to today, when we

\footnotetext{
${ }^{7}$ Similar in spirit to our study, O’Rourke, Taylor, and Williamson (1996) examine the relationship between commodity and factor price convergence across a panel of eleven countries using historical data. As noted here, there are likely large differences in how trade operated in the earlier period of globalization in comparison to today.

${ }^{8}$ Much of the literature on the recent period of globalization has used evidence from changes in trade policy (i.e., tariff liberalization) to understand the impact of trade on wage inequality; however, since trade policy is the outcome of politics, it is an endogenous variable. Several recent studies have exploited additional cross-sectional (industry) and time variation in the data in order to deal with issues of causality (Hanson, 2007; Wei and Wu, 2001; Topalova,
} 
observe a considerable amount of skill-biased technological change, technological innovations in China in this earlier era were more of a complement to than a substitute for unskilled workers in the production process. ${ }^{9}$ For example, in a fast-growing Chinese export sector like cotton textiles, the introduction of new machinery (ring spinning), which improved labor productivity, did not displace the demand for unskilled labor in this industry (Zhao and Chen, 1997). ${ }^{10}$ By contrast, the use of primarily uneducated females grew rapidly in this industry. Government estimates suggest that, between 1912 and 1920, employment in cotton textiles in China grew by $32 \%$, from 228,497 to 301,544 , almost all of which was an expansion in unskilled labor (Ministry of Agriculture and Commerce, 1928, pp. 9-11). We would be the first to acknowledge that if technological change is complementary to unskilled labor, then some of the observed decline in the skill premium may be due to changes in technology. ${ }^{11}$ It should be emphasized, however, that the vast majority of China's exports during the first three decades (in particular, agriculture, handicraft industries, and mining) experienced little technological progress during our sample period (Saxonhouse and Wright, 1984). For example, bristle, one of the leading exports in the first three decades of the twentieth century, was a typical labor-intensive handicraft; most workers employed in its production were uneducated and from low-income, peasant households (You, 1990). Many of the other leading exports in our sample were agricultural and mining products, and the production of these products was unskilled intensive. It thus seems unlikely that technological change was the principal force that drove the precipitous decline in China's skill premium. ${ }^{12}$ We therefore focus our attention on accounting for the effects arising from differences in factor endowments rather than technology.

2004; Goldberg and Pavcnik, 2005.) In this paper, we exploit an alternative source of exogenous variation to identify the impact of trade on wages - World War I - which we argue is an exogenous shock for Chinese trade.

${ }^{9}$ They were often embodied in machines that could be imported from other countries. Indeed, this may have been the motivation for $\mathrm{H}-\mathrm{O}$ to assume that the same technology existed for two countries in their model of trade. Since transport costs fell dramatically during the era in which they wrote (and during part of our sample period), it would have seemed unrealistic to assume that countries couldn't simply have imported technology (embodied in machines) from other countries (Feenstra and Taylor, 2008). See Bond and Van Reenen (1998) for a survey of that skill-biased technological change is a widespread trend observed in many countries during the present period.

${ }^{10}$ Chinese cotton textile factories imported ring-spinning technology from more industrialized countries, which used unskilled labor more intensively than the older technology of mule spinning. The type of technology employed also depended on the quality of cotton used in production. (Saxonhouse and Wright, 1984).

${ }^{11}$ If skill-biased technological change is concentrated in low-skilled sectors, then it could generate a decline in the skill premium, which would be indistinguishable from a fall in the skill premium induced by a trade shock.

${ }^{12}$ Machin and Van Reenen (1998) suggest that technological factors account for a little less than a third of the recent changes in the skill premia in the recent period in the US and UK, but more in some other OECD countries. At the firm or individual level, most studies find a positive correlation between technological change and wages. Estimates range from zero (Doms, Dunne and Troske, 1997) to 2-6\% for each wage group using technology (Casavola, 
Fourth, the growth in the stock of educated workers in China during the first three decades of the twentieth century was likely too small to alter the skill premium significantly. Enrollment rates in secondary schools rose late in the period, but the stock of these newly educated workers was not large enough to affect the wages of skilled workers (Xiong, 1990). And as noted above, unlike today, there appears to have been no surge in demand for skilled workers during this earlier era of globalization so that skill complementarity is less likely to explain the movements in skill premium in China. ${ }^{13}$

Fifth, although workers departed Europe in large numbers and went to the Americas during the nineteenth and early twentieth centuries, China's participation in this wave of global migration was much smaller. Roughly ten million Chinese emigrated between 1840 and 1920, which would translate into an average of a little less than one hundred thousand per year (Ge, Cao, and Wu, 1993, pp.485-6). In relation to the total population of China, roughly 400 million during our sample period, the emigration would have had a negligible effect on wages in China. Hence, it seems reasonable to assume that the effects of emigration on the wages of unskilled workers during our sample period is likely much more muted than in developing countries today. ${ }^{14}$

Sixth, after 1894, foreign direct investment was permitted in China. Scholarship suggests that FDI may have served as a catalyst for China's industrialization. It was most concentrated in the parts of the manufacturing industry that had a greater reliance on advanced machinery. Overall, the total increase in foreign capital flows during our sample period was small and the rate of growth in FDI was fairly steady throughout the first three decades of the twentieth century (Hou, 1965). It exhibits no break or surge around World War I. FDI's effects on the skill

Gavosto and Sestito, 1996). A preponderance of empirical studies use computers to study technological changes' impact on wages;there are concerns that the effects are not causal since the most-advanced technologies (like computers) are often used by the most able workers. These and other econometric issues make it difficult to provide precise estimates of the effects of technological change on wages. For a more complete survey of the literature, see Chennells and Van Reenen (1999).

${ }^{13}$ This is a notable difference from what is observed in developing countries today, like Argentina, Brazil, Mexico, Chile, Colombia, Hong Kong, and India, where the share of skilled workers within industries has increased dramatically over the past two decades (Robbins 1996; Attanasio and Szekely, 2000; Sanchez-Paramo and Schady 2003; Blom, Goldberg, Pavcnik and Schady, 2004; Hsieh and Woo, 2005; and Kijima, 2006).

${ }^{14}$ For example, using data on the recent period of global migration, Mishra (2007) found an 8 percent effect on Mexican wages due to large-scale emigration flows (roughly 1 out of 7 Mexican workers) to the United States between 1970 and 2000; with respect to skill groups, a 10 percent decline in the number of Mexican workers due to emigration raised the average wage by roughly 4 percent. And in Moldova, where roughly 30 percent of the population has recently emigrated, a 10 percent increase in the emigration rate is associated with an average increase in wages in Moldova of around 3.2 percent (Bouton, Saumik, and Tiongson, 2011). 
premium are ambiguous: it may have increased the demand for skilled workers as it has today or, as in the case of the role of technology in early-twentieth-century China, been complementary to unskilled labor. ${ }^{15}$

Seventh, unlike today, when institutions such as unions and minimum or state wages can impact observed wage rates, there is no evidence that the Chinese labor market faced significant regulation; hence the skill premium was not likely influenced by labor market institutions during the first three decades of the twentieth century. ${ }^{16}$ Finally, trade in intermediate products (i.e. outsourcing, offshoring, and "global product sharing") was insignificant in the earlier era of globalization.

\section{Data and Measurement of the Factor Content of Chinese Trade}

We now examine how the Chinese trade boom of the first three decades of the twentieth century affected the skill premium in China. Figure 2 shows that the skill premium rose during the first decade of the twentieth century (when trade expanded, but export prices were relatively constant), but then flattened out and declined as export prices rose and the export boom continued virtually uninterrupted until 1929. ${ }^{17}$ Although the time series graph is broadly consistent with the view that the rapid growth in trade may have impacted the wages of skilled and unskilled workers in China, we subject this hypothesis to more scrutiny by considering

\footnotetext{
${ }^{15}$ Stolper-Samuelson effects assume that labor and capital are mobile within a country, but immobile across borders. However, if we allow for FDI, Rybczinski's Theorem suggests no long-run impact on factor prices. Moreover, factor prices are only affected if two countries lie within the same diversification cone (Slaughter, 2008). There is a large literature suggesting that foreign firms pay workers as much as 30 percent more than comparable domestic firms (Aitken Harrison, and Lipsey, 1996); however, this could be due to differences in the compositions of the workforce. Lipsey and Sjöholm (2004) use plant-level data on Indonesia and educational levels to control for composition of workers, and find wages are 12 percent higher for production workers and $20 \%$ higher for nonproduction workers. Morrissey and Te Velde (2003) present estimates of similar magnitude for five sub-Saharan African countries. Feenstra and Hanson (1997) estimate that U.S. FDI into Mexico had large effects on skilled labor's share of wages, accounting for roughly 50 percent of the increase in its share of wages. Estimates are smaller when individual level data are employed. Using data on Portugal, Martins (2006) finds no evidence of a foreign wage premium Heyman, Sjöholm, and Gustavsson Tingvall (2007) provides similar estimates for Sweden. Other studies for Denmark, Germany, and Norway find small positive wage premiums (between 1 and 3 percent) for foreign firms (Andrews, Schank, and Upward, 2007; Malchow-Moller, Markusen, and Schjerning, 2007; and Balsvik, 2006).

${ }^{16}$ See Machin and Van Reenen (2007) for a discussion of minimum wages and unions in the current period.

${ }^{17}$ If the labor market were completely frictionless, then wages would instantaneously respond to changes in trade. However, since it is highly unlikely labor markets in China were completely frictionless, it is not unexpected that the pattern of the two series is not identical and that changes in wages somewhat lag the growth in trade
} 
whether the factor content of Chinese trade is consistent with the predictions of factor endowments models. ${ }^{18}$

Factor endowment models in the spirit of HOV-SS predict that, as China opened up to trade with the rest of the world and received a boost when export prices rose (beginning around World War I), exports of goods that use relatively more unskilled labor (the abundant factor in China in comparison to skilled labor) in the production process will increase. The demand for unskilled labor will rise as the economy exports more. China will also begin to import more goods that are produced with relatively more skilled labor, thus reducing the domestic demand for skilled labor. As long as the supply curves for labor are not perfectly elastic, the shifts in demand for skilled and unskilled workers will cause the wages of skilled workers to fall relative to unskilled workers. Hence, factor endowment models predict that China's trade boom will cause the skill premium to fall.

\section{A. Data}

To examine the factor content of Chinese trade, we assemble new detailed estimates of exports and imports at the industry level from China Maritime Customs' (hereafter "CMC") trade publications. CMC was likely the only bureaucratic organization in China that operated without interruption (due to wars or funding shortages) from 1858 to 1949. Although it reported to the Chinese government, its top administration as well as its mid-level managers and technocrats were largely foreigners, initially British citizens, but later on also Japanese and Americans. CMC's primary tasks were collecting customs revenue and recording and publishing data on foreign trade; however, it eventually expanded its operations to include collecting revenues from domestic trade, administering the postal system, developing inland and coastal waterways, and representing China at international fairs. CMC's geographical reach grew from just fourteen stations in the 1860s to nearly fifty during the 1920s, covering not only the coastal regions but also inland cities.

CMC published 160 volumes of detailed trade statistics, spanning roughly 90 years of commercial transactions (1858-1949); they are located in archives in Nanjing, China. We constructed our new trade database using these archival publications. CMC collected its data at the port level. Their records include information on the quantities and the values of all

\footnotetext{
${ }^{18}$ See Appendix 1 for details of the calculation of the skill premium.
} 
commodities passing through each treaty port. When aggregated, they also provide a detailed picture of China's trade with the rest of the world. In comparison to other economic or demographic data on China during this period, the quality and detail of the CMC trade data is exceptional and rivals the trade publications of the advanced nations of the late nineteenth century. ${ }^{19}$ Since CMC trade statistics were primarily published at the port level, the units of measurement and currency sometimes varied across ports and over time. We therefore standardized the measurement and currency units and then aggregated the product-level data to the national level.

\section{B. Measurement}

To assess the influence of the expansion in trade on the skill premium in China, we examine the factor content of Chinese exports. We consider differences in production based only on labor characteristics - whether workers were skilled or unskilled. Although this is clearly a simplification, it enables us to combine our detailed trade data with new estimates of Chinese wages from Yan (2008) and further our understanding of the effects of trade and openness during a period of Chinese history when little information on other firm or industry characteristics exists.

After we constructed a database of the quantities and values of all the traded commodities using the CMC publications, we classified exports and imports based on economic activity and skill intensity. To do this, we first selected a standard classification system so that we could systemize the aggregates of economic activity and measure factor content by "industry group.” This is especially important because our database covers Chinese trade for all the treaty ports over three decades, the nomenclature of traded goods sometimes changed, and the individual customhouses sometimes collected trade statistics using their own naming systems.

Since the Standard Industrial Classification System (SIC) was not adopted in major industrial surveys or censuses, it has limited usefulness for the wide variety of commodities in our Chinese trade data. Instead, we use the Index of Occupations and Industries from the 1950 U.S. Census of Population (“IND1950”). The basic content of the occupational and industrial classification was largely derived from earlier censuses, in particular, the 1940 Census. Since IND1950 is somewhat retrospective in design, it provides a consistent set of industry codes that

\footnotetext{
${ }^{19}$ Trade statistics report types and destinations of trade, so that we are able to ensure that trade is not double counted.
} 
is broad enough to capture the trade being conducted by China between 1903 and 1928. In fact, all the imported and exported commodities of China in our sample period can be grouped into different categories of IND1950. Exported commodities are grouped into 40 IND1950 groups, and imported commodities are grouped into 53 IND1950 groups.

Next, we classified industries according to skill intensity. Since there is no agreed upon methodology for determining the factor content of products or industries, empirical studies use a variety of approaches to proxy factor content. One way to proxy for skill intensity is to rank industries by average education levels; here the assumption is that higher skilled occupations require more education. Another approach is to calculate the share of production workers (relative to non-production workers) or to examine the factor utilization in each industry. A third approach is to rank industries according to average wages. If workers are paid their marginal products (as would prevail in competitive markets for factors and goods), then, on average, higher paying industries theoretically ought to reflect higher average productivity or skill.

Because U.S. historical census data provides broad industry coverage and detailed information on education and wages, we use it as one means for classifying skill intensity for Chinese industries, though we also consider a robustness check using a more limited data set based on Chinese manufacturing data. The 1940 census is the first year in which the U.S. census provided information on an individual's education. The 1940 Census records each individual's highest level of educational attainment, ranging from no education to five or more years of postsecondary education. In our analysis, we classify workers with nine or more years of education as skilled workers. We count the numbers of skilled and unskilled employees in the 1940 Census for each industry (using the IND1950 classification described above) and then calculate the fraction of workers in each industry that had nine or more years of education. We denote industries where the fraction of workers with nine or more years of education exceeded 0.48 as skilled industries. We divide the data at this value since the two industries above and below this cutoff seemed most dissimilar in terms of labor force characteristics (motor vehicles and motor vehicle equipment versus glass and glass products). ${ }^{20}$

Benchmarking on the U.S. historical census relies on several strong assumptions, such as the existence of the same technologies in the U.S. and China, the same skill intensities of these technologies in the two countries, and the same productivity of factors used in production.

Values of export are F.O.B and values of imports are C.I.F. 
Moreover, as Helpman (1999) and others have pointed out, skill-abundant countries will, in any industry, use more skilled labor than others, and unskilled labor in these countries will have a relatively higher productivity (Maskus and Nishioka, 2009). To assess whether using U.S. factor intensities is a reasonable assumption, we examined whether the ordinal rankings are stable over time. We collected the factor intensity data based on education for the U.S. in 1990, and examined its correlation with the 1940 measures. The correlation coefficient is 0.837 , suggesting that the rankings do not change over time. Hence, if 1900 data were available for the U.S., we suspect our results would be quite similar.

As previously mentioned, the 1940 U.S. Census also records each individual's annual wage, allowing us to aggregate these data and obtain average industry wages (again based on IND1950 industry classification). We can thus compute an alternative measure of skill intensity at the industry level based on wages (reported in Appendix Table A2). ${ }^{21}$ Of course, inter-industry wage differentials are ubiquitous, such that wages for observationally identical workers differ by industry. The skill intensities based on wages can therefore, at best, be viewed as a robustness check. That said, the classification of industries as skilled and unskilled based on average earnings is nevertheless quite similar to the classification using education. ${ }^{22}$

During our sample period, Chinese industries primarily adopted new technologies from leading industrial countries such as the U.S (Xu and Wu, 2003), so technologies and their factor contents were likely to be fairly similar. That said, they may not have been identical, as is assumed in an HOV model. Because this assumption and others may not have held in practice, we construct an alternative measure of skill intensity at the industry level based on Chinese industry data. Unfortunately, survey data at the individual, occupational, or industry level for China during the first three decades of the twentieth century are very scarce. The 1928 Shanghai Census we employ is the earliest survey that contains information sufficient to derive estimates of skill intensity at the industry level. It was administered by the Bureau of Industry, Agriculture, and Commerce of the Greater Shanghai Municipality and includes information on factory names,

\footnotetext{
${ }^{20}$ The results reported later in the paper do not appear that sensitive to changing these cutoffs.

${ }^{21}$ In a similar way, we also divided the industry data into skilled and unskilled using log wages. Industries with log wage values greater than 2.986 are classified as skilled, which puts metal mining and pottery producing as the two industries on the dividing line.

${ }^{22}$ Comparing the wage-based measure of skill intensity with the education measure yields a Spearman rank correlation coefficient of 0.75 ; it is significantly different from 0 at conventional levels of significance. Moreover, just as we observed with education, the classification of wages is stable over time. Comparing the 1940 wage data measures with 1990 measures yields a correlation coefficients of 0.668.
} 
addresses, ownership, capitalization, number of workers, wages, raw materials, and power utilization.

Importantly, the Shanghai survey records information on inputs, which can be used to compute the capital-labor ratios and evaluate the skill intensity of industries; however, the number of industries that can be classified is smaller than if we use the U.S. census information. ${ }^{23}$ For these calculations, we assume that industries which use more labor (relative to capital) are, on average, characterized by lower-skilled workers. ${ }^{24}$ We first classified the traded goods using the classification system adopted in the 1928 Shanghai Survey, and then calculated the capital-labor ratio by dividing the total physical capital (value of physical capital stock) by the number of workers in each industry. We then ranked the traded goods industries according to their capital-labor ratios (Appendix Table A3). We denote industries where the capital-labor ratio exceeded 640 as skilled industries. We divide the data at this value since the two industries above and below this cutoff seemed most dissimilar in terms of labor force characteristics (tools and instruments versus textiles).

\section{Analyzing the Effects of the Chinese Trade Boom on Wages}

\section{A. Factor Content Analysis}

A first test in the spirit of factor endowments models is to examine whether total exports were becoming more unskilled-intensive in their composition over our sample period. Using the data on industry averages for education, we classify the industrial sectors into two broad groups, unskilled and skilled. Figure 4 displays the composition of exports and imports based on factor content. In 1903, when the magnitude of foreign trade was fairly small and China was relatively closed, most of its imports and exports were composed of unskilled-intensive products. However, as Chinese trade grew in importance over the next 25 years, we see significant movements in the ratios for both exports and imports. As shown in Panel A of Figure 4, exports became more unskilled-intensive over the entire sample period - rising from about 0.92 to 0.99 .

\footnotetext{
${ }^{23}$ It also records the highest and lowest wage rates by industry, but these would likely produce unreliable estimates for computing factor intensity.

${ }^{24}$ Recent studies on manufacturing from the late-nineteenth and early-twentieth centuries suggest that more capitalintensive industries paid higher wages (Atack, Bateman and Margo, 2004). In fact, the growth of manufacturing in that era was often accompanied by an increase in capital per worker and in the use of inanimate power sources,
} 
In contrast, the share of unskilled imports declined substantially, falling from 0.88 to 0.75 . In a similar vein, Panel B of Figure 4 shows the fraction of imports that are skill-intensive increased from 0.11 to 0.25 over the sample period. The trend towards more unskilled intensive exports and more skill-intensive imports is particularly pronounced after 1913. Results are quite similar if we use alternative measures of skill intensity, based on capital-labor ratios or average wages (reported in Appendix Figure 1).

Another way of assessing the general factor content of trade is to examine the detailed industry data. In Figure 5, we display the value of exports and imports for each industry on the yaxis and its corresponding skill intensity on the X-axis for 1903 (Panel A) and 1928 (Panel B). (Skill intensity, measured by educational attainment, increases as we move in a rightward direction along the x-axis.) Figure 5 shows that exports are largely clustered at the lower levels of skill intensity whereas imports dominate the highest values of skill intensity. The relatively greater unskilled intensity of Chinese exports and the greater skill intensity of its imports are even more evident by 1928. The results are similar if we employ other measures of skill intensity (as seen in Appendix Figure 2).

These results constitute strong evidence that trade was fundamentally responding in ways that are consistent with factor endowments models of trade. Even if we found no evidence that the unskilled-intensive exports were rising over our sample period, the factor content data could still be consistent with the predictions of factor endowments models if it were true that, overall, Chinese exports grew faster for unskilled-intensive industries than for skill-intensive industries. This would indicate that the expansion in exports shown in Figure 1 was driven by unskilledintensive exports. (Similarly, skill-intensive imports should grow faster than those for unskilled industries.)

To test this alternative prediction, we divide the data into ten industry groups based on skill intensity and then compute the growth rates for each decile. Using these industry groupings allows us to examine products of similar skill intensity and follow them over the entire sample period. We weight the deciles by their share of the total value of exports, and then plot the growth rate of exports for each group relative to its skill intensity. Within the industry groups, imported product groups are very stable over the sample period; however, because new export industries arise during the first decades of the $20^{\text {th }}$ century (e.g., cotton textiles) (and old skilled

particularly steam and, after the turn of the century, electricity. This higher level of capital and energy use reflected 
exports in 1903 dropped in 1928), there is some shifting of products within industry groups for exports. $^{25}$

Figures 6-9 graph the average annual growth rates for exports and imports from 1903 to 1928 where industry groups are ordered by skill intensity, using either the educational attainment or capital-labor measures (as indicated on the x-axis of the graphs). These plots show that the fastest growing deciles for exports tended to be those with the lowest skill intensity. Indeed, since such a large preponderance of exports use unskilled labor intensively, the visual impact of the graph is diminished since there is no way to include all the zero values of industries (not exported) that would be more skill intensive. On the other hand, the fastest growing deciles for imports tended to be the most skill intensive.

\section{B. Evidence on Changes in Relative Prices of Traded Goods}

Factor endowment theories suggest that changes in product prices are the mechanism that alters trade flows and factor prices. Therefore, a necessary condition for trade to impact the skill premium is a change in the relative price of traded goods and services. We have thus far shown that China became more specialized in producing and exporting unskilled intensive commodities. Assuming the marginal product of workers has not changed, if export prices rise relative to import prices, Stolper-Samuelson suggests that the skill premium in China will eventually fall, since Chinese exports use relatively more unskilled labor in their production. We therefore calculate the terms of trade for China during our sample period to further elucidate the link between output prices and factor prices. ${ }^{26}$

To capture the relevant measure of domestic prices (i.e., the prices that producers receive and that consumers pay), we divide F.O.B. export prices by C.I.F. import prices using the unit

\footnotetext{
the installation of machines, and these activities were complementary to skilled labor, such as that of engineers.

${ }^{25}$ If, for example, we held the products constant over the entire sample period for exports, the qualitative findings would not change. Figure 6 would be more skewed toward unskilled groups and there would be even fewer skilled exports (i.e., smaller skilled bubbles). Figure 7 would hardly change because the composition of China's imports displays very little change over the sample period.

${ }^{26}$ Beyer, Rojas, and Vergara (1999) examine changes in Chile’s terms of trade to assess how trade openness alters the skill premium. They use a relative wholesale price index of textile products to proxy the terms of trade, on the grounds that this relative index largely captures the price evolution of all labor intensive goods in Chile. In contrast to their approach, we don't have to use the price of a particular industry to proxy for the terms of trade since we have unit value data from the CMC that allows us to directly compute the terms of trade.
} 
value data from our CMC database. ${ }^{27}$ C.I.F. measures for Chinese imports include transportation (freight) and insurance costs (Cheng, 1956; Hsiao, 1974). Since trade costs are passed along to consumers as part of the final price, they face the C.I.F. price; exporters receive the F.O.B. price on goods they sell.

Figure 10 shows that the relative price of exports to imports fell by roughly 50 percent between 1906 and 1920. Nearly all of this decline took place during World War I. The large decline in the relative price of exports before 1920 largely resulted from soaring prices of imported goods during World War I. Freight costs and insurance rates rose dramatically during the war years. Mohammed and Williamson (2004, p.180) show that a nominal freight rates index for a representative Asian trade route increased from 0.702 in 1914 to 14.874 by 1918 - an increase of more than 2,000 percent. ${ }^{28}$ Since we use C.I.F. values for imports, our terms of trade index captures the wartime increase in trade costs, and masks the dramatic and sustained rise in Chinese export prices that was also occurring. As we show below, export prices boomed during the war. Trade costs declined with the cessation of hostilities, and as a result, relative prices quickly recovered after 1920. Figure 10 shows that the terms of trade grew by more than 60 percent between 1920 and $1926 .{ }^{29}$ Demand for Chinese exports continued in the postwar period, further pushing up Chinese export prices.

The large rise in transportation and insurance costs during the war thus delayed the immediate impact of the Chinese export boom on the skill premium. In the first two decades of the twentieth century, relative prices declined by about 40 percent and the skill premium rose by more than 20 percent. In the eight years after 1920, relative prices rose by 60 percent, and the skill premium declined by almost 10 percent. This pattern indicates that rising sales and prices of Chinese products after 1920 led to growing revenue for exporting firms, providing considerable scope for raising the wages of unskilled workers that were used intensively in their production.

To better understand what was going in the export sector, we make use of the unit value data contained in our database to compute the growth rates in prices for China's ten most important exports. Figure 11 shows positive average annual growth rates in unit values for these

\footnotetext{
${ }^{27}$ The prices are obtained by dividing values by quantities using our CMC trade data. Hsiao (1974) also reports the aggregate trade values and quantities, which can be used to calculate aggregate export and import prices. Since his data also are based CMC data, the results using his published series are nearly identical.

${ }^{28}$ Using a global index, real freight rates roughly tripled during World War I, according to Mohammed and Williamson (2004, p.88).
} 
major exports over the period 1903 to 1928. For nine of the ten chief exports, the growth rates were faster after 1914 (Panel B), suggesting the war further stimulated demand. Chow tests confirm that there is a highly statistically significant structural break in export prices at the start of World War I. ${ }^{30}$ The Chow break test is significant at the $1 \%$ level for an aggregate index of export prices. We also examined whether there was a structural break for each of the ten principal exports of China. Nine out of ten exports exhibited statistically significant structural breaks at the outbreak of World War I (tea being the exception). These results further suggest that the upward movement in unit values for exports associated with World War I was a widespread phenomenon and not merely related to one particular export, such as cotton yarn. These price changes, however, likely had muted effects on wages until the unusually high transportation and insurance costs associated with World War I declined, causing export prices to rise relative to import prices.

In addition, the commodities shown in Figure 11 that used unskilled labor more intensively (agricultural goods and cotton yarn) experienced particularly strong rates of growth in their prices. Figure 12 shows that prices in cotton yarn grew by 275 percent after 1913. Cotton spinning was widely considered a typical unskilled-intensive manufacturing industry. China had been a large importer of cotton yarn, but by the beginning in the twentieth century, a domestic cotton textile industry began to compete with foreign products. The industry grew rapidly, and by the mid-1920s, cotton-spinning exports exceeded imports.

As the cotton spinning industry expanded, it drew in large numbers of unskilled workers. Real wages in cotton textiles increased by more than 50\% during the war, remained at those levels after the war ended, and then continued an upward trajectory into the 1920s (Liu 1936). Although additional industry-level wage data are quite scarce, we were able to obtain figures for real wages for two other key exports. Real wages in the silk industry grew by more than 150\% during the war and then, after flattening out at the conclusion of the war, continued their upward trajectory. Similarly, real wages for coal workers (based on Kailun, one of the largest mines in

\footnotetext{
${ }^{29}$ The export prices shown in Figure 12 are the prices in silver. The export prices relative to the price of gold show similar qualitative results.

${ }^{30}$ Four of the 10 principal exports were statistically significant at the $1 \%$ level, 2 were significant at $5 \%$ level, and 3 were significant at $10 \%$ level.
} 
China at that time) grew by more than $25 \%$ during the $1920 \mathrm{~s}^{31}$ These data suggest that wages were rising in the export sector in response to higher product prices.

It is certainly possible that compositional changes in the exports or quality improvements account for some change in unit values, however our data suggest otherwise. As noted earlier, China's small quantity of exports at the start of our sample period largely consisted of the same types of products that were exported at the end of the period. The trade boom associated with World War I drew more resources into the production of the same range of goods. And, as Figure 11 shows, China’s exports were simple manufactures or homogeneous agriculture goods, so quality improvements during the period were likely unimportant.

\section{Difference-in-Differences Estimates of the Effects of World War I on Exports}

To complement the evidence from our skill intensity graphs and from the terms of trade data, we now test whether World War I affected trade along the lines of SS. That is, we explore whether unskilled sectors experienced more growth in exports as a result of the war boom and changing terms of trade. We estimate a panel regression of the following form:

$$
\text { Exports }_{i t}=\mathrm{b}_{\mathrm{o}}+\mathrm{b}_{1} \text { WorldWarI }_{t}+\mathrm{b}_{2} \text { skill }_{i}+\mathrm{b}_{3}\left(\text { WorldWarI }_{t}^{*} \text { skill }_{i}\right)+\mathrm{e}_{\mathrm{it}} \text {, }
$$

where Exports $_{i t}$ is the (log) annual value of exports in industry $i$, WorldWarI $_{t}$ is an indicator variable that equals 1 in 1914 and thereafter, and skill is a measure of industry-level skill intensity. The coefficient of interest is $b_{3}$, the interaction between the World War I indicator variable and skill intensity. The model predicts that if the war had a lasting and differentially stronger effect on exports in unskilled- intensive industries, the coefficient on $b_{3}$ will be negative and statistically significant. And since World War I was an exogenous shock to Chinese exports, the reported coefficients on World War I and its interaction take on a causal interpretation.

Table 2 presents fixed effects regression estimates for a balanced panel of 17 industries, covering the period 1903-28. In Panel A, we present results where the skill intensity is defined as an indicator variable, where the top third of industries are coded as skill intensive. The interaction effect can then be interpreted as the average effect that skill intensity has on exports

\footnotetext{
${ }^{31}$ We were unable to locate data for real wages in the coal industry prior to 1919 or for other key export industries so that we could carry out a more detailed statistical analysis in a panel setting. Recall, the wage data from Yan (2008) are occupational and not at the industry level.
} 
after WWI commenced. For both measures of skill intensity for which we have a broad number of industries we can classify (i.e., educational attainment and average wages), we report a variety of specifications that include industry and year fixed effects (to account for omitted variables) as well as a fully interacted model that examines the within-industry variation over time. Standard errors are clustered at the industry level.

The coefficient on the World War I indicator variable is large and positive in all the specifications reported in Panel A. The estimated coefficient suggests that after the World War I commenced, exports grew by between 92\% and 263\%, depending on the specification. Consistent with our prediction, the interaction term $b_{3}$ is negative and statistically significant, suggesting that unskilled-intensive sectors received an additional boost after 1914. For example, using the results from column 2 of panel A and calculating the combined effect of the World War I indicator and its interaction with skill intensity, we find that unskilled exports outpaced skilled exports by $139.9 \%$ after the war began.

As a robustness check, Panel B of Table 2 uses each industry's actual value of skill intensity rather than the dummy variable. These specifications have a stronger interpretation. An observed negative coefficient on the interaction term implies that the more unskilled intensive an industry is, the more it will export after the war began. Here again, we find a statistically significant and negative effect on the interaction, suggesting that exports of unskilled intensive industries grew more quickly after the war started. To give a sense of the magnitude of the effect, we compare the results for the most skilled and least skilled sectors using the results from Column 5 of Panel B (i.e., those based on using the educational attainment measure of skill intensity). The difference in the change in exports after World War I of the least skill-intensive industry versus the most skilled is roughly $150 \%$.

Given that we present evidence from a quasi-natural experiment, we can conclude that industries that used unskilled workers more intensively had faster trade growth due to the effects of World War I. Although it is impossible to rule out alternative explanations, the movements in the skill premium data seem most consistent with a trade shock rather than either a dramatic rise in the quantity of skilled workers in the 1920s or very rapid technological change. The limited data available on Chinese education rates from our sample period suggest that the expansion of skilled workers due to increased opportunities was small and likely came too late in our sample period to account for the observed decline in the skill premium. As noted earlier, some 
technological advances in China appear to have been ongoing in industries like cotton textiles, and they tended to raise the demand for unskilled workers rather than displace them. It is therefore possible that some of the boost in trade we observe during our sample period is associated with technological change in manufacturing, which perhaps resulted from the foreign direct investment into China from Japan and other countries at the beginning of the $20^{\text {th }}$ century. Nevertheless, in cotton textiles and other mechanized manufacturing industries in China, the pace of technological change was incremental. There were no sudden surges that occurred in the 1910s and 1920s that would be consistent with the rather abrupt reversal in the wage premium over these decades. If anything, the pace of technological change was slower during the war period due to the difficulty of importing new machinery from western countries engaged in combat. The reversal in the upward trend and flattening out of the skill premium that occurred during this decade would therefore be inconsistent with technology being the main driver. Moreover, in the vast majority of other sectors of the economy, particularly agriculture, handicraft industries, and mining, there was little technological progress during the first three decades of the twentieth century.

\section{Model and Simulation}

\section{A. Benchmark Model}

To better understand trade's contribution to the change in the skill premium in the 1910s and 1920s, we now model a price shock to Chinese exports in a general-equilibrium, factorendowment framework. We then simulate this model using data on the Chinese economy to examine whether our empirical findings are plausible and consistent with theory. We first consider a closed economy model as a benchmark. In the subsequent subsection, we extend the dynamic model to an open economy subject to price shocks. The model yields predictions similar to standard 2x2x2 HOV models, but has the advantage of allowing us to track variables dynamically and then simulate the effect of a price shock on the home country's trade.

Suppose there are two intermediate goods and one final good. ${ }^{32}$ Prices of intermediate goods are denoted as $p_{t}{ }^{1}$ and $p_{t}{ }^{2}$ and $p_{t}^{f}$ is the price of the final good. We set the second

\footnotetext{
${ }^{32}$ We specify production this way since many developing countries import intermediate goods and export final goods.
} 
intermediate good as a numeraire and hence normalize $p_{t}^{2}$ to be 1 . Output for the final good, $Y_{t}^{f}$, is produced using a standard CES specification where

$$
Y_{t}^{f}=\left[\gamma\left(Y_{t}^{1}\right)^{\frac{\varepsilon-1}{\varepsilon}}+(1-\gamma)\left(Y_{t}^{2}\right)^{\frac{\varepsilon-1}{\varepsilon}}\right]^{\frac{\varepsilon}{\varepsilon-1}}
$$

where $Y_{t}^{1}$ and $Y_{t}^{2}$ are intermediate goods, $\gamma$ and $1-\gamma$ are the relative shares of two intermediate goods, and $\varepsilon$ is the elasticity of substitution between two intermediate goods. By profit maximization,

$$
\frac{Y_{t}^{1}}{Y_{t}^{2}}=\left(\frac{\gamma}{1-\gamma} \frac{1}{p_{t}^{1}}\right)^{\varepsilon}
$$

Thus we have

$$
p_{t}^{f}=\left(\gamma^{\varepsilon}\left(p_{t}^{1}\right)^{1-\varepsilon}+(1-\gamma)^{\varepsilon}\right)^{\frac{1}{1-\varepsilon}}
$$

The production for intermediate good 1 uses unskilled labor, $L_{t}{ }^{1}$, and land, $T$, with the shares $\delta$ and $1-\delta$ respectively. Land has a fixed supply, so we normalize the supply of land to be $1 .^{33}$ Hence, we specify the production function of intermediate good 1 as the following:

$$
Y_{t}^{1}=A^{1}\left(L_{t}^{1}\right)^{\delta}
$$

where $0<\delta<1$. For simplicity, we assume the technology used to produce intermediate good 1 , $A^{1}$, is constant. Assuming labor markets are perfectly competitive, the wage for unskilled labor will be equal to its average product:

$$
w_{t}^{1}=p_{t}^{1} A^{1}\left(L_{t}^{1}\right)^{\delta-1} .
$$

On the other hand, the production of intermediate good 2 uses both skilled and unskilled labor and is specified as a constant returns to scale production function:

$$
Y_{t}^{2}=A_{t}^{2}\left(H_{t}^{2}\right)^{\alpha}\left(L_{t}^{2}\right)^{1-\alpha},
$$

where $H_{t}{ }^{2}$ and $L_{t}^{2}$ are skilled and unskilled labor, respectively. The shares of these two inputs are $\alpha$ and $1-\alpha$, respectively. Again, assuming perfectly competitive labor markets, the wage for skilled labor, $w_{t}{ }^{H}$, and that of unskilled labor, $w_{t}{ }^{L, 2}$ are their marginal products:

$$
w_{t}^{H}=\alpha A_{t}^{2}\left(H_{t}\right)^{\alpha-1}\left(L_{t}^{2}\right)^{1-\alpha},
$$

\footnotetext{
${ }^{33}$ In this version of the model, we aim to illustrate how differences in labor affect production and therefore abstract from the role of capital in the production of the two intermediate goods; however, adding capital would not change the qualitative results of this model.
} 


$$
w_{t}^{L, 2}=(1-\alpha) A_{t}^{2}\left(H_{t}\right)^{\alpha}\left(L_{t}^{2}\right)^{-\alpha} .
$$

Since unskilled labor can move freely among all the sectors, wages for unskilled labor will equalize across all the sectors of the economy. ${ }^{34}$ Therefore,

$$
w_{t}^{L}=w_{t}^{1}=w_{t}^{L, 2} .
$$

Hence, we define the skill premium as

$$
s_{t}=\frac{w_{t}^{H}}{w_{t}^{L}}=\frac{\alpha}{1-\alpha} \frac{L_{t}^{2}}{H} .
$$

We assume that the technology used for the production of intermediate good 1 grows slower than that in intermediate good 2. We make this assumption to characterize the fact that the productivity of the industrial sector improves rapidly through modernization (perhaps even through the importation of foreign technologies). Without losing generality, we simplify the model by assuming that $A_{1}$ is constant over time, while $A_{2}$ grows at a positive rate of $g$, i.e.

$$
A_{t+1}^{2}=(1+g) A_{t}^{2} .
$$

In our model, there are two types of consumers that optimize over their lifetimes. Consumer $i, i \in\{L, H\}$, maximizes lifetime utility as specified by a CRRA utility function:

$$
\sum_{t=0}^{\infty} \beta^{t} \frac{\left(c_{t}^{i}\right)^{1-\sigma}-1}{1-\sigma} .
$$

Consumers can borrow and lend at interest rate, $r$, in any period, which is exogenous to our model. Therefore, the budget constraint of consumer $i, i \in\{L, H\}$, is:

$$
\sum_{t=0}^{\infty} \frac{p_{t} c_{t}^{i}}{(1+r)^{t}} \leq \sum_{t=0}^{\infty} \frac{w_{t}^{i}}{(1+r)^{t}} .
$$

To optimize utility, the consumer thus maximizes equation (12) subject to (13).

We also assume the total supply of skilled workers is fixed at $H$ and the total supply of unskilled labor is fixed at $L$ so that the market-clearing conditions for the labor market are:

$$
\begin{gathered}
H=H_{t}, \\
L=L_{t}{ }^{1}+L_{t}{ }^{2} .
\end{gathered}
$$

We define a competitive equilibrium as follows:

\footnotetext{
${ }^{34}$ We assume perfect wage equalization to simplify the model; however, relaxing this assumption to allow for differences in wages across sectors does not change the qualitative results.
} 
Definition of Competitive Equilibrium: A competitive equilibrium consists of consumption $\left\{c_{t}{ }^{L}, c_{t}{ }^{H}\right\}$, production of each good $\left\{Y_{t}^{f}, Y_{t}^{1}, Y_{t}^{2}\right\}$, labor supply $\{H, L\}$, labor demand $\left\{L_{t}^{1}, L_{t}{ }^{2}, H_{t}\right\}$, wages $\left\{w_{t}{ }^{L}, w_{t}^{H}\right\}$, prices of final good and two intermediate goods $\left\{p_{t}{ }^{f}, p_{t}{ }^{1}, p_{t}{ }^{2}\right\}$, and a law of motion $g$ for the state variable, technology, such that:

(1) consumption is the solution to the utility maximization problem;

(2) labor demand and wages satisfy equations (5), (7), (8) and (9);

(3) labor supply is fixed;

(4) labor supply and labor demand satisfy equations (14) and (15);

(5) the law of motion $g$ satisfies equation (11);

(6) the price of intermediate good satisfies equations (2) and (9);

(7) the price of final good satisfies equation (3); and

(8) the production of each good satisfies equations (1), (4), and (6).

\section{B. An Open Economy Model with Price Shocks}

We now extend the model to describe an open economy with exogenous terms of trade shocks. To relate the open economy version of the model to our empirical analysis of China, we assume the home country is abundant in unskilled labor and scarce in skilled labor. When the home country opens up, it begins to export the final good. Trade shocks are modeled as exogenous increases in the prices of the final good. Price shocks induce the home country to import more intermediate goods from abroad to produce and export more of the final good. Following factor endowment theories, we assume the home country therefore has a comparative advantage in producing intermediate good 1 and a comparative disadvantage in producing intermediate good 2. It will therefore import intermediate good 2 in order to raise the production and export of the final good.

Based on this framework, the market for the final good can be described by:

$$
Y_{t}^{f}+E X_{t}=\left(\gamma\left(Y_{t}^{1}\right)^{\frac{\varepsilon-1}{\varepsilon}}+(1-\gamma)\left(Y_{t}^{2}+I M_{t}\right)^{\frac{\varepsilon-1}{\varepsilon}}\right)^{\frac{\varepsilon}{\varepsilon-1}},
$$

where $Y_{t}^{f}$ is domestic consumption of the final good, $E X_{t}$ is the amount of final good exported, $Y_{t}^{2}$ is domestic production of intermediate good 2, and $I M_{t}$ is the quantity of intermediate good 2 imported. 
We assume that the home country is a small economy and is thus a price taker in the market for both the final good and intermediate good 2. Therefore, $p_{t}^{f}$ and $p_{t}{ }^{2}$ are exogenous and determined by global supply and demand. Since we have not modeled the capital account, we assume balance of trade for each period so that:

$$
p_{t}^{f} E X_{t}=p_{t}^{2} I M_{t} .
$$

\section{Analysis and Simulation of the Skill Premium}

We now examine how the skill premium evolves in the two versions of the model. In the benchmark closed-economy model, since the total factor productivity (TFP) of intermediate good 2 grows over time while the TFP of intermediate good 1 is constant, unskilled labor will migrate out of the production of intermediate good 1 and into the production of intermediate good 2 until the asymptotic steady state is reached. As described by equation (10), the skill premium will therefore rise until it becomes flat after reaching the asymptotic steady state. If we conceptualize intermediate good 1 as describing production in the agricultural sector, and intermediate good 2 as describing the industrial sector, the benchmark model describes the rising skill premium that is typically associated with industrialization and faster TFP growth in the industrial sector.

In the open economy model, the skill premium evolves differently. A persistent increase in the price of the final good induces the home country to produce and export more of the final good, using intermediate goods produced domestically (by both skilled and unskilled labor) as well as some that are imported from abroad. Since the home country has a comparative advantage in producing intermediate good 1 , it will import intermediate good 2 . In contrast to the benchmark model, the open economy model will slow down the migration of unskilled labor from intermediate good 1 to intermediate good 2 since unskilled labor is needed in order to produce more of the final good for the global market. If the price shocks are sufficiently large and persistent, unskilled labor will move back into the production of intermediate good 1 , thus driving down the home country's skill premium. The production of intermediate good 2 in the home country shrinks, and the home country imports intermediate good 2 to produce the final good.

We can show this by solving the close form of the model. Equation (11) shows that the skill premium depends solely on $L_{t}{ }^{2}$, the amount of unskilled labor used in producing 
intermediate good 2. Hence, we need to solve the relationship between price shocks and unskilled employment in the sector of intermediate good 2.

Assuming profit maximization and the production function for the final good shown in equation (16): we obtain the following optimal condition

$$
\frac{Y_{t}^{1}}{Y_{t}^{2}+I M_{t}}=\left(\frac{\gamma}{1-\gamma} \frac{p_{t}^{2}}{p_{t}^{1}}\right)^{\varepsilon} .
$$

Plugging this back to equation (16), we have

$$
p_{t}^{f}=\left(\gamma^{\varepsilon}\left(p_{t}^{1}\right)^{1-\varepsilon}+(1-\gamma)^{\varepsilon}\left(p_{t}^{2}\right)^{1-\varepsilon}\right)^{\frac{1}{1-\varepsilon}}
$$

Given equation (10), the unskilled wages in two sectors are equal. This yields

$$
p_{t}^{1} A^{1}\left(L_{t}^{1}\right)^{\delta-1}=p_{t}^{2}(1-\alpha) A_{t}^{2} H^{\alpha}\left(L_{t}^{2}\right)^{-\alpha} .
$$

Again, we set the second intermediate good as a numeraire and hence normalize $p_{t}^{2}$ to be 1 . Equation (19) shows that the price of intermediate good $1, p_{t}{ }^{1}$, will increase as the price of the final good, $p_{t}{ }^{f}$, rises. Equation (20) shows that, as long as $p_{t}{ }^{1}$ rises faster than $A_{t}{ }^{2}, L_{t}{ }^{1}$ will increase and $L_{t}{ }^{2}$ will decrease so that the equation holds. In other words, the increase in the price of intermediate good 1 tends to attract unskilled workers to move back into the production of intermediate good 1 , and by equation (10), this will reduce the skill premium.

We simulate our general equilibrium model using computational methods so that we can consider the effects of the exogenous price shock of World War I on Chinese exports and the skill premium. We use parameters from the existing literature and the actual data on the prices of Chinese trade to conduct a simulation. The values and sources of parameters are shown in Table 3. We also feed the actual price indices of Chinese imports and exports from 1914 to 1928 into our simulation.

Figure 13 shows three lines: the actual skill premium, the skill premium produced by simulating the model, and a "counterfactual" simulation. The figure shows that the simulation produces a decline in the skill premium around the same time as what is observed in the data. The reduction in the skill premium is somewhat more pronounced in the simulation than in the actual data (roughly 13\% versus 10\%), but the change in the slope is consistent with what the observed Chinese data. There are several reasons why the model produces a sharper decline in the skill premium than the actual data. First, the model assumes a finite horizon, with the shock 
ending in 1928, while in the real world, agents maximize utilities over a much longer horizon. Second, the model also assumes balanced trade for each year in the model whereas China's actual trade was unbalanced. Third, physical capital accumulation and other dynamic mechanisms, not included in the model, also affect the skill premium in the real world. Despite the differences in the magnitudes of decline, the model successfully shows that price shocks to the terms of trade are capable of driving down the skill premium, a prediction consistent with factor endowment theories of trade. The counterfactual simulation (the third line shown in Figure 13) uses a terms of trade series where we net out the effects that World War I had on raising the price of imports (due to higher insurance and shipping rates). This counterfactual simulation shows that the decline in the skill premium would have began even earlier, during the war years, and when prices in Chinese exports began to boom. Hence, the higher cost of imports during the war somewhat slowed the effects of China's trade boom on the skill premium.

\section{Conclusion}

Our findings suggest that the opening of China to trade during the first three decades of the twentieth century and the shock of World War I led to a dramatic expansion in exports. Prices of exports, especially those for unskilled goods, grew rapidly, particularly after 1913. Difference-in-differences regression estimates of the effects of the war on China's industry-level exports show that World War I boosted exports, and that it boosted exports substantially more for unskilled industries than skilled industries in China. Exports continued their upward trajectory as China's products were integrated into the global trade network, and after wartime transport costs fell, Chinese terms of trade dramatically improved in the 1920s. China may have also benefited from learning and dynamic economies of scale (Krugman, 1987), allowing it to retain its export industriess in the face of post-wartime competition. Rising foreign demand for Chinese exports led to greater specialization and increased production of unskilled-intensive products. Unskilledintensive exports, already dominant in Chinese trade, increased their share of total trade over these decades.

Once export prices began to rise dramatically during the second decade of the trade boom, wages of unskilled workers relative to skilled workers changed sufficiently to alter the slope of the skill premium. By the 1920s, the skill premium had reversed course and declined by roughly 8 percent, consistent with the improving terms of trade of China. Although one cannot 
completely rule out alternative explanations, our empirical evidence suggests that the causality likely runs from trade to wages. We simulate an open economy model and show that a price shock such as World War I can largely replicate the observed movements in China's exports and skill premium. Moreover, a counterfactual simulation shows that if import prices had not risen due to trade costs associated with the war, the decline in the skill premium would have been sharper in the 1910s.

Our findings suggest that when trade was dominated by the movement of relatively homogenous goods across borders, it may have had a considerable impact on wages. The declining wage inequality in China during the second two decades of the twentieth century stands in contrast to studies examining the recent period of globalization, which emphasize how trade and globalization has widened skill premia in developing countries (Goldberg and Pavcnik, 2007). The growth in Chinese exports during the first three decades of the twentieth century was centered on products that used unskilled labor intensively. We have suggested that this earlier era of globalization was less influenced by trade in intermediate inputs (i.e., outsourcing), increases in capital flows, and complementarity of capital with skilled labor - factors that have played a role in widening skill premiums today in developing countries. ${ }^{35}$ However, as emphasized in the research on the current period of globalization, we acknowledge that our findings pertain only to China and may not generalize to other developing countries even during our sample period, since countries experienced globalization in different ways and at different times.

\footnotetext{
${ }^{35}$ The observed decline in the skill premium in China also seems inconsistent with Melitz-type models of "firm upgrading" in that these predict a higher demand for skilled workers as trade openness occurs; this suggests that these models may be less well suited for explaining trade-induced movements in the skill premium during the first era of globalization.
} 


\section{References}

Acemoglu, Daron and Fabrizio Zilibotti. 2001. “Productivity Differences.” Quarterly Journal of Economics 116 (2): 563-606.

Aitken, B., A.E. Harrison and Robert Lipsey. 1996. "Wages and Foreign Ownership: A Comparative

Study of Mexico, Venezuela, and the United States.” Journal of International Economics 40(3/4): 345371.

Andrews, M., L. Bellmann, T. Schank and R. Upward. 2007. “The Takeover and Selection Effects of Foreign Ownership in Germany: An Analysis Using Linked Worker-Firm Data.” GEP Research Paper, 2007/08.

Atack, Jeremy, Fred Bateman, and Robert A. Margo. 2004. Journal of Economic History 64(1): 172-92.

Attanasio, O. and M. Szekely. 2000. "Household Saving in East Asia and Latin America: Inequality Demographics and All That.” In B. Pleskovic and N. Stern (eds.), Annual World Bank Conference on Development Economics 2000. Washington, DC: World Bank.

Baldwin, Robert E. and Glen G. Cain. 2000. "Shifts in Relative U.S. Wages: The Role of Trade, Technology, and Factor Endowments.” Review of Economics and Statistics 82(4): 580-595.

Balsvik, R. (2006). "Is Mobility of labour a channel for spillovers from multinationals to local domestic firms?” Norwegian School of Economics (unpublished paper).

Bhagwati, Jagdish. 1991. “Free Traders and Free Immigrationists: Strangers or Friends?” Russell Sage Foundation Working Paper.

Beyer H., P. Rojas, and R. Vergara. 1999. “Trade liberalization and wage inequality.” Journal of Development Economics 59(1): 103-123.

Blom, Andreas; Pinelopi Goldberg; Nina Pavcnik and Norbert Schady. 2004. “Trade Policy and Industry Wage Structure: Evidence from Brazil.” World Bank Economic Review: 18(3): 319-344.

Bond, Eric W., Kathleen Trask and Ping Wang, 2003. "Factor Accumulation and Trade: Dynamic Comparative Advantage with Endogenous Physical and Human Capital," International Economic Review, vol. 44(3), pages 1041-1060.

Bond, Stephen and John Van Reenen. 2006. Micro-Econometric Models of Investment and Employment. In James Heckman and Edward Leamer (eds.) Handbook of Econometrics, vol. 6, North Holland.

Bouton, Lawrence, Paul Saumik, and Erwin R. Tiongson. 2011. "The Impact of Emigration on Source Country Wages: Evidence from the Republic of Moldova.” Policy Research Working Paper 5764, World Bank.

Burstein, Ariel and Jonathan Vogel. 2009. “Globalization, Technology, and the Skill Premium.” Columbia University Working paper (October). 
Casavola, Paola, Andrea Gavosto and Paolo Sestito. 1996. "Technical progress and wage dispersion in Italy: evidence from firms’ data.” Annales d'Economie et de Statistique, Jan-June: 387-412.

Cheng, Yu-Kwei. 1956. Foreign Trade and Industrial Development of China. University Press of Washington, D. C.

Lucy Chennells and John Van Reenen. 1999. "Has Technology Hurt Less Skilled Workers? An Econometric Survey of the Effects of Technical Change on the Structure of Pay and Jobs.” Institute for Fiscal Studies. Working Paper Series No. 99/27.

Doepke, Matthias. 2004. “Accounting for Fertility Decline during the Transition to Growth.” Journal of Economic Growth. 9(3): 347-83.

Doms, Mark, Timothy Dunne, and Kenneth R. Troske. 1997. "Workers, Wages and Technology.” Quarterly Journal of Economics 112(1): 253-289.

Estevadeordal, Antoni and Alan M. Taylor. 2002. “Testing Trade Theory in Ohlin's Time.” In Bertil Ohlin: A Centennial Celebration 1899-1999, edited by Ronald Findlay, Lars Jonung, and Mats Lundahl. Cambridge: MIT Press.

Feenstra, Robert C., and Gordon H. Hanson. 1995. "Foreign Investment, Outsourcing, and Relative Wages.” In Robert. C. Feenstra and Gene. M. Grossman (eds.) Political Economy of Trade Policy: Essays in Honor of Jagdish Bhagwati Cambridge, MA: The MIT Press.

Feenstra, Robert C., and Gordon H. Hanson. 1997. "Foreign Direct Investment and Relative Wages: Evidence from Mexico’s Maquiladoras.” Journal of International Economics 42:371-93.

Feenstra, Robert. C. and Alan M. Taylor. 2008. International Economics. New York: Worth Publishers.

Feliciano, Zadia. 2001. "Workers and Trade Liberalization: The Impact of Trade Reforms in Mexico on Wages and Employment.” Industrial and Labor Relations Review 55(1): 95-115.

Findlay, Ronald and Kevin O’Rourke. 2003. “Commodity Market Integration.” In Globalization in Historical Perspective, edited by Michael D. Bordo, Alan M. Taylor, Jeffrey G. Williamson. Chicago: University of Chicago Press.

Galiani, Sebastian and Guido G. Porto. 2010. “Trends in Tariff Reforms and in the Structure of Wages.” Review of Economics and Statistics. 92(3): 482-494.

Galiani, Sebastian and P. Sanguinetti. 2003. “The Impact of Trade Liberalization on Wage

Inequality: Evidence from Argentina.” Journal of Development Economics 72: 497-513.

Gasparini, Leonardo. 2003. "Different Lives: Inequality in Latin America and the Caribbean." Unpublished Paper. Universidad Nacional de la Plata. .

Glick, Reuven and Alan M. Taylor. 2006. “Collateral Damage: Trade Disruption and the Economic Impact of War.” NBER Working Paper 11565.

Goldberg, Pinelope and Nina Pavcnik. 2004. “Trade, Inequality, and Poverty: What Do We Know? 
Evidence from Recent Trade Liberalization Episodes in Developing Countries.” Brookings

Trade Forum 2004: 223-269.

Goldberg, Pinelope and Nina. Pavcnik 2005. "Trade Protection and Wages: Evidence from the Colombian Trade Reforms.” Journal of International Economics 66 (1): 75-105.

Goldberg, Pinelope and Nina Pavcnik. 2007. "Distributional Effects of Globalization in Developing Countries.” Journal of Economic Literature March 45(1): 39-82.

Hanson, Gordon. 2004. "What Has Happened to Wages in Mexico since NAFTA?", in T. Estevadeordal, D. Rodrik, A. Taylor, A. Velasco, eds., FTAA and Beyond: Prospects for Integration in the Americas, Cambridge: Harvard University Press.

—. 2007. “Globalization, Labor Income, and Poverty in Mexico,” in Ann Harrison, ed., Globalization and Poverty, Chicago: University of Chicago Press and the National Bureau of Economic Research.

Harrison, Ann and Gordon Hanson (1999). "Who Gains From Trade Reforms? Some Remaining

Puzzles.” Journal of Development Economics 59: 125-154.

Helpman Elhanan. 1999. “The Structure of Foreign Trade.” Journal of Economic Perspectives, 13(2): 121-144.

Heyman, F., F. Sjöholm and P. Gustavsson Tingvall. 2007. "Is there Really a Foreign Ownership Wage Premium? Evidence from Matched Employer-Employee Data.”Journal of International Economics.

Hsiao, Liang-lin. 1974. China's Foreign Trade Statistics, 1864-1949. Cambridge, MA: Harvard University Press.

Hsieh, Chang-Tai and Keong T.Woo. 2005. “The Impact of Outsourcing to China on Hong-Kong's Labor Market,” American Economic Review. 95: 1673-87.

Hou, Chi-ming. 1965. Foreign Investment and Economic Development in China, 1840-1937. Cambridge, Massachusetts: Harvard University Press.

Ge, Jianxiong, Shuji Cao, and Songdi Wu. 1993. A Brief History of Migration in China. Fuzhou, China: People’s Press of Fujian.

Kijama, Yoko. 2006. “Why did wage inequality increase? Evidence from urban India 1983-99.” Journal of Development Economic. 81: 97-117.

Krugman, Paul. 1987. “The Narrow Moving Band, the Dutch Disease, and the Consequences of Mrs. Thatcher: Notes on Trade in the Presence of Dynamic Scale Economies.” Journal of Development Economics 27: 41-55. . 2008. “Trade and Wages Reconsidered.” Brookings Papers on Economic Activity. 2008(1): 103-54.

Lawrence, Robert Z. 2008. "Blue-collar blues: Is trade to blame for rising US income inequality?" Institute for International Economics. Working Paper. 
Lawrence, Robert Z. and Matthew J Slaughter. 1993. "International Trade and American Wages in the 1980s: Giant Sucking Sound or Small Hiccup?” Brookings Papers on Economic Activity (Microeconomics): 161-210.

Leamer, Edward. 1995. “The Heckscher-Ohlin Model in Theory and Practice.” Princeton Studies in International Finance no. 77. . 1988. "In Search of Stoloper-Samuelson Linkages.” In Imports, Exports, and the American Worker, edited by Susan Collins, Washington, D.C.: Brookings, 141-214.

Lipsey, R.E and F. Sjöholm. 2004. "FDI and Wage Spillovers in Indonesian Manufacturing." Review of World Economics 140(2): 321-332.

Liu, Dajun. 1936. The Growth and Industrialization of Shanghai. Shanghai: China Institute of Pacific Relations.

Machin, Stephen and John Van Reenen. 1998. "Technology and Changes in Skill Structure: Evidence From Seven OECD Countries.” Quarterly Journal of Economics 113(4): 1215-1244.

Machin, Stephen and John Van Reenen. 2007. “Changes in Wage Inequality.” Centre for Ecoonomic Performance Special Paper No. 17 (April).

Malchow Møller, N., J. Markusen and B. Schjerning. 2007. “Foreign Firms, Domestic Workers.” NBER Working Paper. 13001.

Martins, P. 2006. “Do Foreign Firms Really Pay Higher Wages? Evidence from Different Estimators.” Unpublished paper.

Maskus, Keith E. and Nishioka Shuichiro. 2009. "Development-related biases in factor productivities and the HOV model of trade," Canadian Journal of Economics 42(2): 519-553.

Melitz, Marc J. 2003. “The Impact of Trade on Intra-industry Reallocations and Aggregate Industry Productivity,” Econometrica 71(6): 1695-1725.

Ministry of Agriculture and Commerce. 1928. The First Labor Yearbook of China.

Mitchener, Kris James and Hans-Joachim Voth. 2011. “Trading Silver for Gold: Nineteenth-Century Asian Exports and the Political Economy of Currency Unions.” in Barro and Lee, eds., Costs and Benefits of Economic Integration in Asia, Oxford University Press.

Mishra, Prachi. 2007. “Emigration and Wages in Source Countries: Evidence from Mexico,” Journal of Development Economics 82(1): 180-199.

Mohammed, Saif I. Shah and Jeffrey G. Williamson. 2004. "Freight Rates and Productivity Gains in British Tramp Shipping 1869-1950.” Explorations in Economic History 41(2): 172-203.

Morrisey, O. and D.W. Te Velde (2003). "Do Workers in Africa Get a Wage Premium if Employed in Firms Owned by Foreigners?” Journal of African Economies 12(1): 41-73. 
Mussa, Michael, 1978. "Dynamic Adjustment in the Heckscher-Ohlin-Samuelson Model," Journal of Political Economy, vol. 86(5), pages 775-91.

O’Rourke Kevin H. and Jeffrey G. Williamson. 1994. "Late-nineteenth Century Anglo-American Factor Price Convergence: Were Heckscher and Ohlin Right?” Journal of Economic History, 54(12): 892-916.

O’Rourke, Kevin H, Alan Taylor, Jeffrey G. Williamson. 1996. "Factor Price Convergence in the Late Nineteenth Century.” International Economic Review 37 (August): 499-530.

Revenga, Anna L. 1992. “Exporting Jobs? The Impact of Import Competition on Employment and Wags in U.S. Manufacturing.” Quarterly Journal of Economics, 107(1): 255-84. . 1997. "Employment and Wage Effects of Trade Liberalization: The Case of

Mexican Manufacturing,” Journal of Labor Economics 15: 520-543.

Robbins, Donald J. 1996. “Evidence on Trade and Wages in the Developing World.” OECD Technical Paper No. 119.

Robertson, Raymond. 2000. “Trade Liberalization and Wage Inequality: Lessons from the Mexican Experience.” World Economy 23: 827-849. . 2004. "Relative Prices and Wage inequality: Evidence from Mexico.” Journal of International Economics 64(3): 387-409.

Sachs, Jeffrey D. and Howard Shatz. 1994. “Trade and Jobs in U.S. Manufacturing.” Brookings Papers on Economic Activity: 1-84.

Sanchez-Paramo, Carolina. and Norbert Schady. 2003.“Off and Running? Technology, Trade, and the Rising Demand for Skilled Workers in Latin America,” World Bank Policy Research Working Paper 3015. Washington, DC: World Bank.

Slaughter, Matthew J. 1998. "What Are the Results of Product-Price Studies and What Can We Learn From Their Differences?” In Robert C. Feenstra (ed.) International Trade and Wages, National Bureau of Economic Research Conference.

Slaughter, Matthew J. 1998. “International Trade and Labour-Market Outcomes: Results, Questions, and Policy Options.” Economic Journal 108: 1452-1462.

Saxonhouse, Gary R. and Gavin Wright. 1984. "New Evidence on the Stubborn English Mule and Cotton Industry, 1878-1920.” Economic History Review 37(4): 507-19.

Topalova, Petia. 2004. "Factor Immobility and Regional Impacts of Trade Liberalization: Evidence on Poverty and Inequality from India.” Unpublished paper, Yale University.

United States Bureau of Statistics. 1950. 1950 Census of Popualtion, Alphabetical Index of Occupations and Industries. Washington: U.S. G.P.O.

Wan, Guanghua, Ming Lu, Zhao Chen. 2007. “Globalization and Regional Income Inequality: Evidence from within China.” Review of Income and Wealth 53(1): 35-59. 
Wei, Shang Jin, and Yi Wu. 2001. “Globalization and Inequality: Evidence from within China.” NBER Working Paper 8611.

Wood, Adrian. 1995. "How Trade Hurt Unskilled Workers”. Journal of Economic Perspectives 9(3): 5780

—. 1998. "Globalisation and the Rise in Labour Market Inequalities.” The Economic Journal 108(450): 1463-1482.

Xiong, Ming'an. 1990. The History of Education in Republican China (“Zhonghua Minguo Jiaoyu Shi”). Chongqing, China: Chongqing Publishing House.

Xu, Dixin and Chengming Wu. 2003. The History of the Development of China's Capitalism ("Zhongguo Ziben Zhuyi Fazhan Shi”). Beijing, China: People’s Publishing House.

Yan, Se. 2008. Real Wages and Skill Premia in China, 1858 to 1936. Ph.D. Dissertation, UCLA.

You, Shimin. 1990. Historical Materials of Trade in Sichuan for the Modern Period. Chengdu, China: Sichuan University Press.

Zhao, Gang, and Zhongyi Chen. 1997. History of Chinese Cotton Textile Industry. Beijing, China: China Agriculture Press. 
Table 1 Leading Chinese Exports, by Product, 1903-1928

Units: Thousand of piculs (for coal: thousands of tons)

\begin{tabular}{cccccc}
\hline \hline Year & Raw Cotton & Tea & Ground nut & Bristle & Cotton yarn \\
\hline 1903 & 760 & 1678 & 157 & 40 & \\
1914 & 675 & 1496 & 592 & 51 & 4 \\
1919 & 1072 & 690 & 137 & 52 & 67 \\
1928 & 1112 & 926 & 933 & 67 & 350 \\
\hline \hline \multicolumn{7}{r}{ Year } & Coal & Bean cake & Wheat Flour & Raw silk & Vegetable Oil \\
\hline 1903 & 76 & 3404 & & 211 & 421 \\
1914 & 2006 & 10769 & 70 & 226 & 1304 \\
1919 & 1477 & 20725 & 2694 & 346 & 4199 \\
1928 & 3885 & 21352 & 86 & 435 & 2368 \\
\hline \hline
\end{tabular}

Source: Hsiao (1974) 


\section{Table 2. The Effects of World War I on Chinese Exports}

(Dependent Variable: Annual Log of Exports)

Panel A: Results using a skill intensity indicator variable based on average wages or average education

\begin{tabular}{lllllll}
\hline \hline & $(1)$ & $(2)$ & $(3)$ & $(4)$ & $(5)$ & $(6)$ \\
\hline World War I & 1.29 & 1.21 & & 0.65 & 1.10 & \\
& {$[0.20]^{* * *}$} & {$[0.09]^{* * *}$} & & {$[0.23]^{* * *}$} & {$[0.09]^{* * *}$} & \\
Wage indicator & -0.87 & & & & & \\
& {$[0.25]^{* * *}$} & & & & & \\
Wage x WWI & -2.09 & -0.54 & -0.47 & & & \\
& {$[0.38]^{* * *}$} & {$[0.17]^{* * *}$} & {$[0.14]^{* * *}$} & & & \\
Education indicator & & & & -0.71 & & \\
& & & & {$[0.29]^{* *}$} & & \\
Education x WWI & & & & -1.31 & -0.24 & -0.22 \\
& & & & {$[0.46]^{* * *}$} & {$[0.20]$} & {$[0.16]$} \\
Constant & 15.97 & 18.46 & 17.75 & 15.86 & 18.52 & 17.80 \\
& {$[0.15]^{* * *}$} & {$[0.11]^{* * *}$} & {$[0.27]^{* * *}$} & {$[0.14]^{* * *}$} & {$[0.10]^{* * *}$} & {$[0.27]^{* * *}$} \\
Industry FE & NO & YES & YES & NO & YES & YES \\
Year FE & NO & NO & YES & NO & NO & YES \\
R-sq & 0.31 & 0.90 & 0.94 & 0.11 & 0.90 & 0.94 \\
N & 348 & 348 & 348 & 348 & 348 & 348 \\
\hline \hline
\end{tabular}

Panel B: Results using a continuous measures of industry skill intensity, based on average wages or education

\begin{tabular}{lllllll}
\hline \hline & $(1)$ & $(2)$ & $(3)$ & $(4)$ & $(5)$ & $(6)$ \\
\hline World War I & 7.30 & 2.67 & & 4.13 & 2.28 & \\
& {$[1.32]^{* * *}$} & {$[0.70]^{* * *}$} & & {$[0.67]^{* * *}$} & {$[0.40]^{* * *}$} & \\
Log wage & -1.34 & & & & & \\
& {$[0.12]^{* * *}$} & & & & & \\
Log wage x WWI & -1.02 & -0.24 & -0.23 & & & \\
& {$[0.21]^{* * *}$} & {$[0.10]^{* *}$} & {$[0.07]^{* * *}$} & & & \\
Average education & & & & -5.33 & & -2.89 \\
& & & & {$[1.15]^{* * *}$} & & {$[0.77]^{* * *}$} \\
Education x WWI & & & & -8.76 & -2.99 & 17.54 \\
& & & & {$[1.53]^{* * *}$} & {$[0.93]^{* * *}$} & \\
Constant & 24.65 & 18.31 & 17.60 & 17.97 & 18.25 & YES \\
& {$[0.81]^{* * *}$} & {$[0.17]^{* * *}$} & {$[0.28]^{* * *}$} & {$[0.52]^{* * *}$} & {$[0.16]^{* * *}$} & {$[0.29]^{* * *}$} \\
Industry FE & NO & YES & YES & NO & YES & YES \\
Year FE & NO & NO & YES & NO & NO & 0.94 \\
R-sq & 0.31 & 0.90 & 0.94 & 0.29 & 0.90 & 348 \\
N & 348 & 348 & 348 & 348 & 348 & \\
\hline \hline
\end{tabular}

Notes: Standard errors in parentheses. All regressions use robust standard errors. ${ }^{* * *} \mathrm{p}<0.01,{ }^{* *} \mathrm{p}<0.05$, $^{*} \mathrm{p}<0.1$ 
Table 3. Parameters for Simulation

\begin{tabular}{cc}
\hline \hline & \\
Parameter & Values \\
& \\
\hline$\gamma$ & 0.5 \\
$\varepsilon$ & 3 \\
$\alpha$ & 0.78 \\
$\delta$ & 0.6 \\
$A^{1}$ & 0.22 \\
$A^{2}$ & 1.04 \\
$g$ & 0.01 \\
$H$ & 1 \\
$L$ & 200 \\
\hline \hline
\end{tabular}

Sources of Parameters:

1. We set the value of $\gamma$ arbitrarily to equal 0.5 , which means the two intermediate goods are equally important in production. Results do not appear sensitive to other values.

2. $\varepsilon$ : Burstein and Vogel (2009).

3. $\alpha$, and $\delta$ : Doepke (2004) .

4. $\quad A^{1}$ and $A^{2}$ : Acemoglu and Zilibiotti (2001).

5. $g, H$ and $L$ : are set according to historical estimates of the labor force in China. 
Figure 1. The Value of China's Foreign Trade

Panel A: Nominal value of trade

(Thousands of Haikwan Tael)

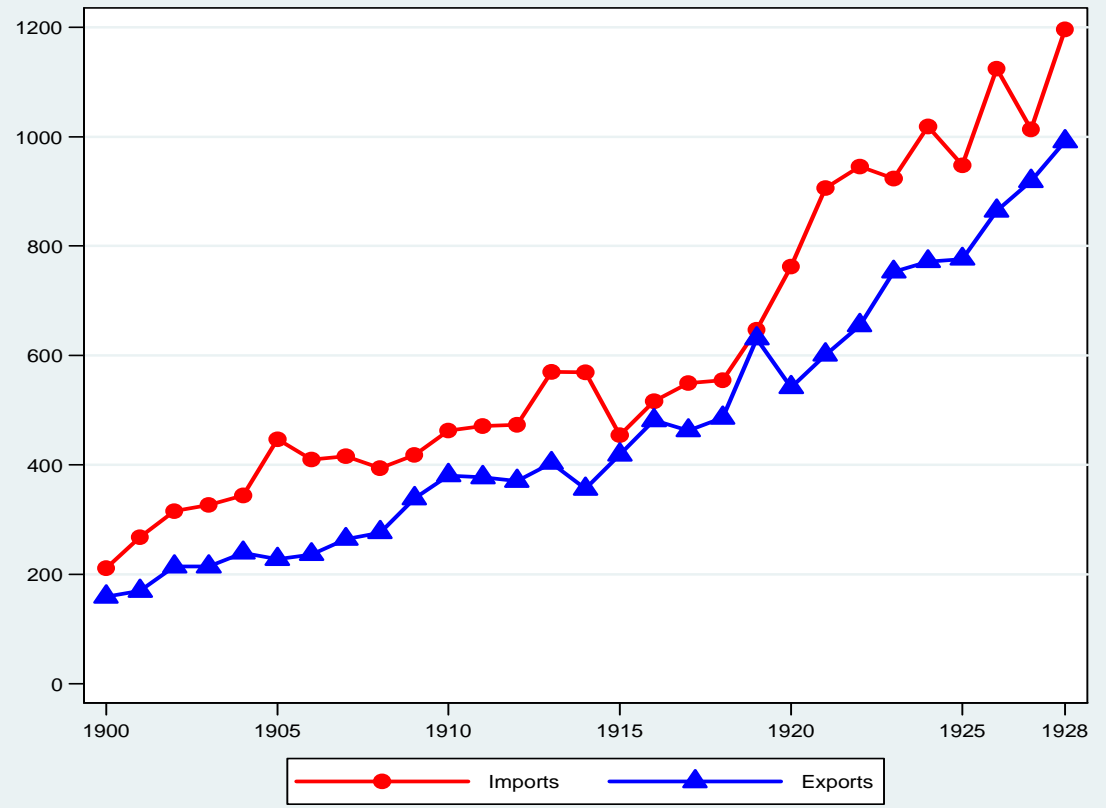

Source: Hsiao (1974)

Panel B: Real value of trade (Index: 1900=100)

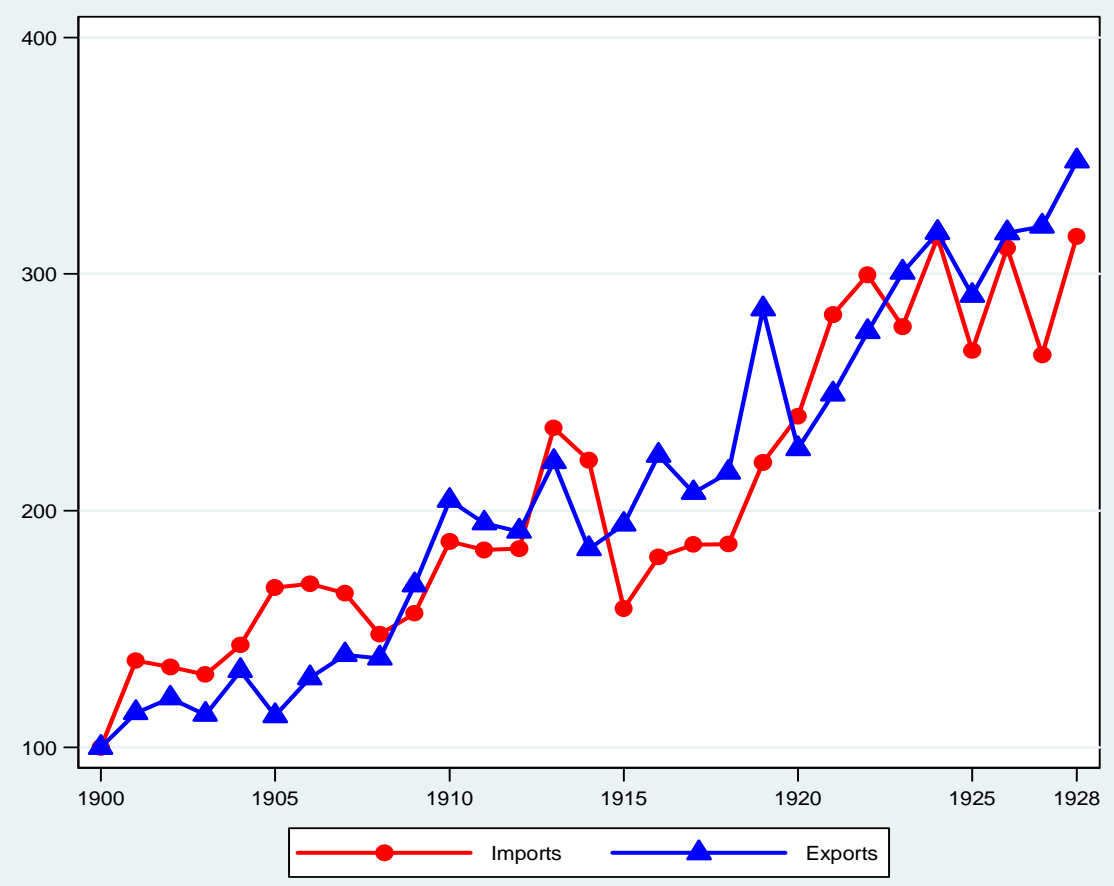

Source: Authors' calculations based on data from Hsiao (1974). 
Figure 2. Real Wage Premium in China

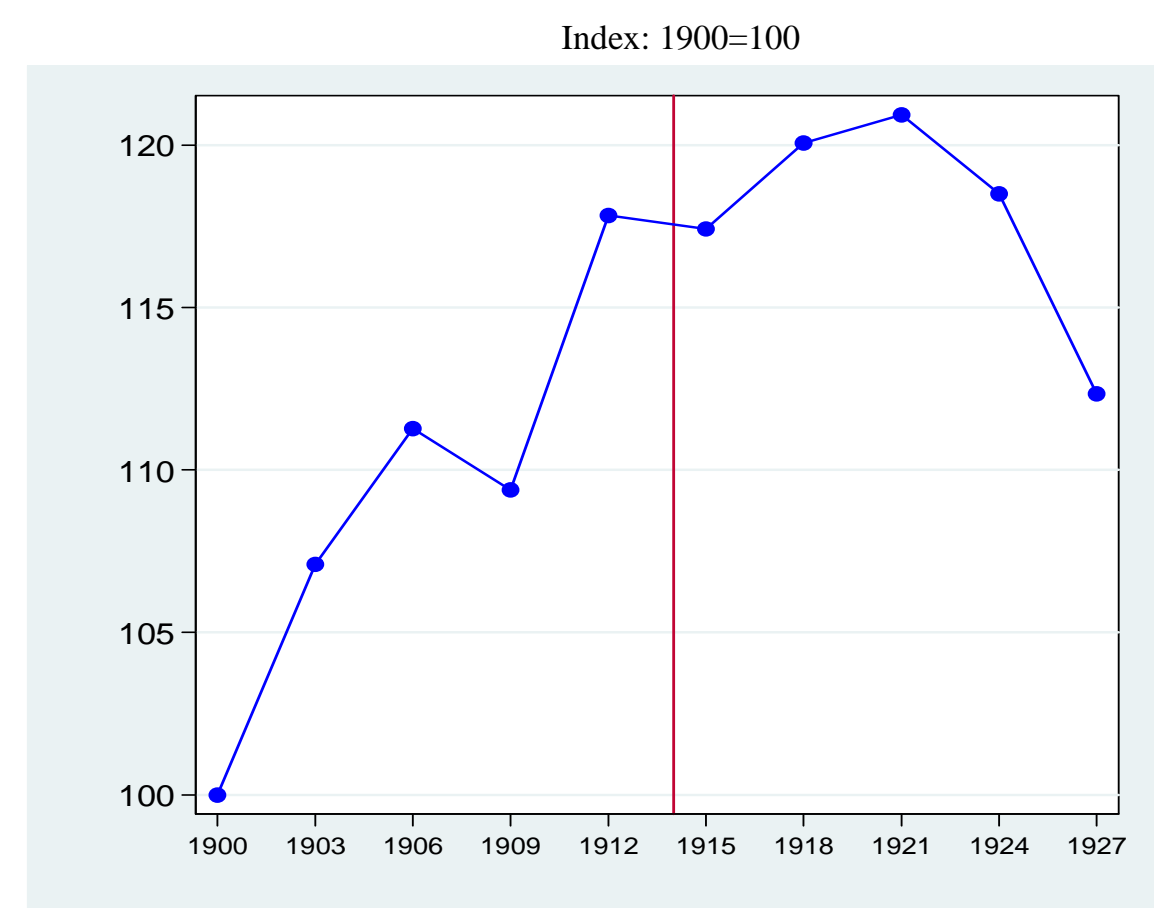

Source: See Appendix 1.

Figure 3. Quantities of Foreign Imports and Exports of Cotton Yarn, 1910-1935

Unit: thousands of piculs

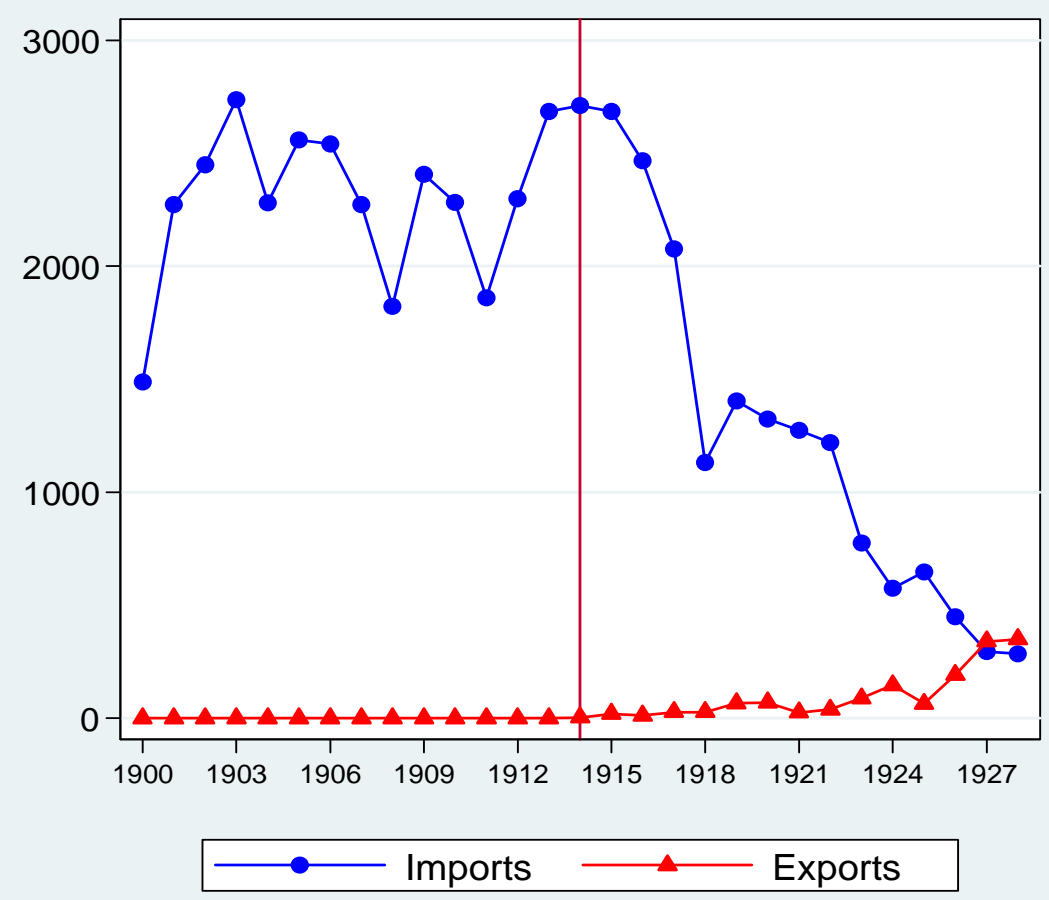

Source: Hsiao (1974). 
Figure 4. Export and Import Shares by Skill Intensity, 1903-1928

Panel A: Unskilled trade

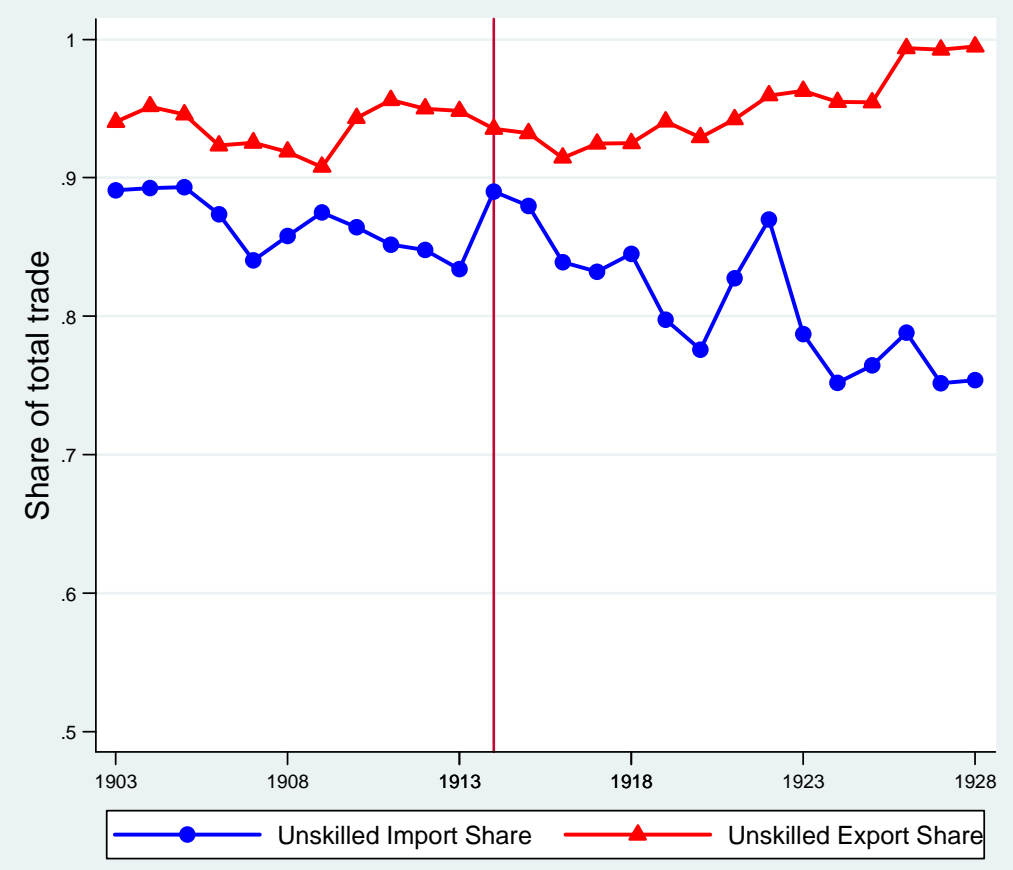

Panel B: Skilled Trade

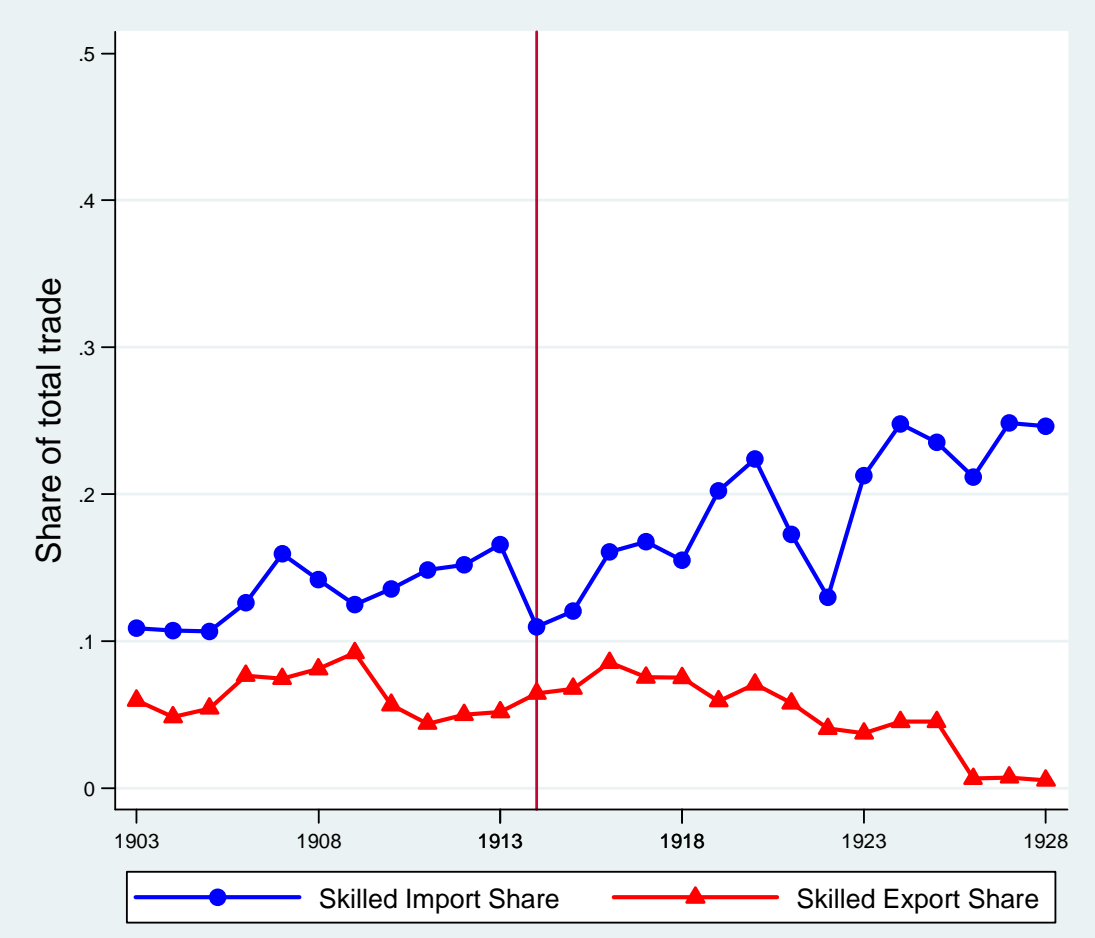

Notes: Skill intensity is classified by educational attainment using data from the 1940 US census. See the text for further details. 
Figure 5. Value of Exports and Imports by Skill Intensity, 1903 and 1928

(Thousands of Haikwan Tael)

Panel A: 1903

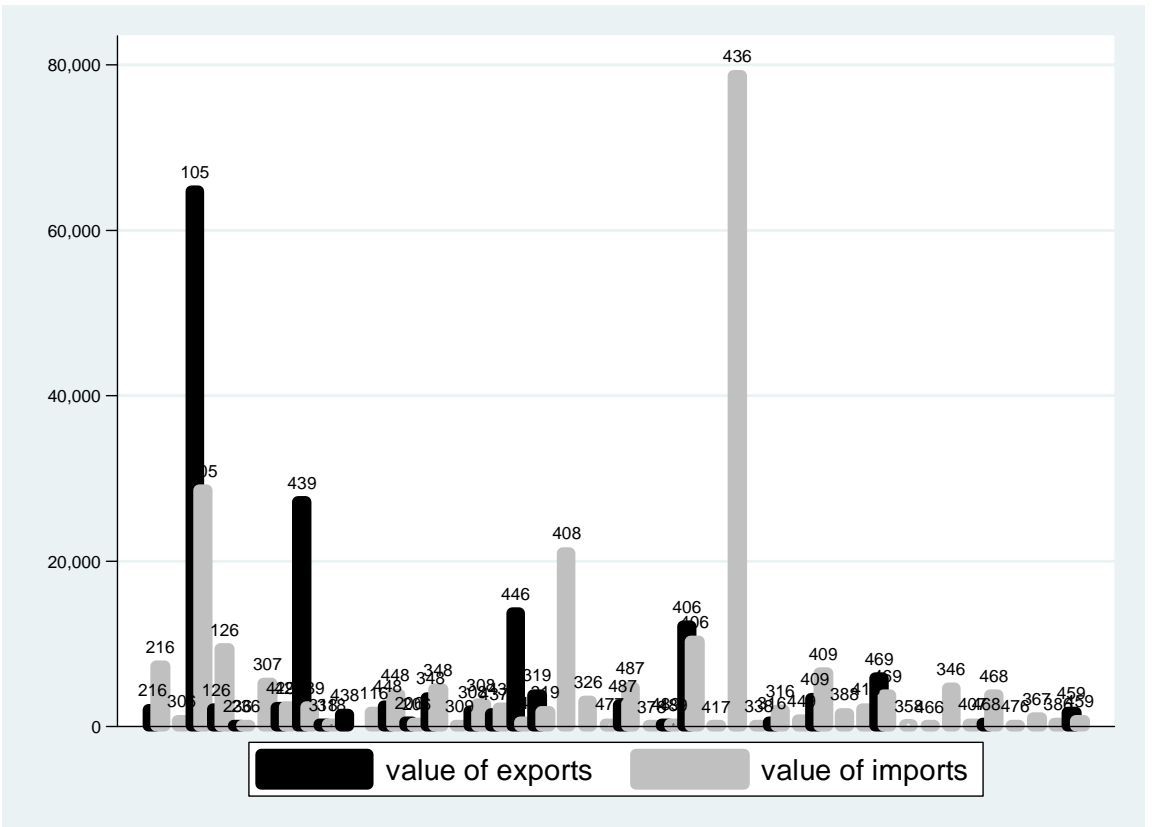

Panel B: 1928

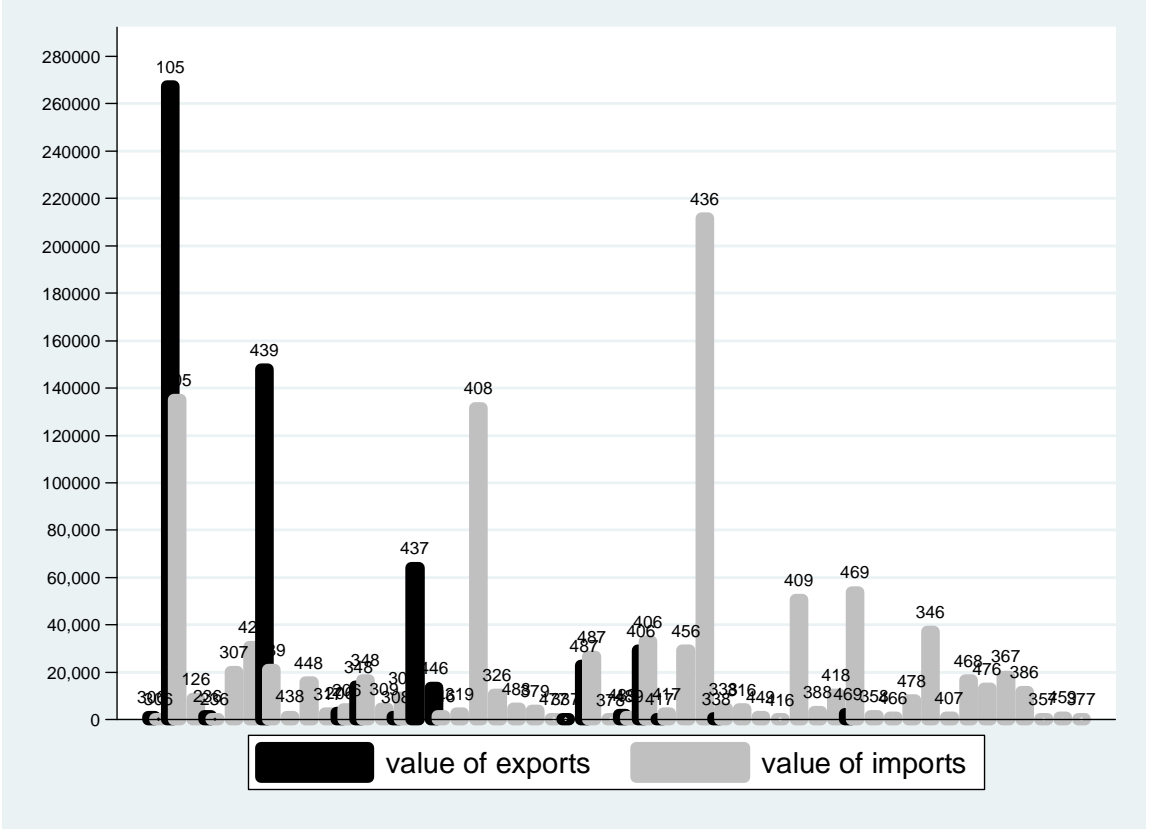

Source: Skill intensity is classified by educational attainment as described in the text. Numbers on individual bars correspond to industry codes listed in Appendix Tables A1 and A2. 
Figure 6. Skill Intensity and the Growth Rate of Exports from 1903 to 1928

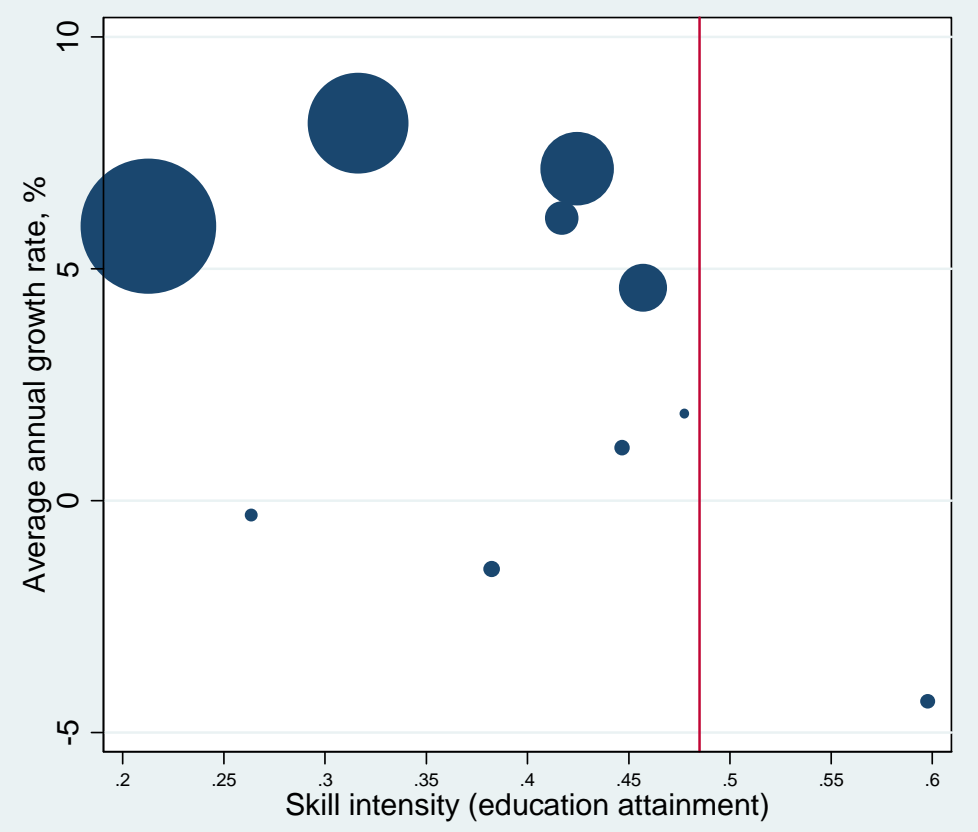

Source: Authors' calculation as described in the text. Skill intensity based on data from the 1940 US census.

Figure 7. Skill Intensity and the Growth Rate of Imports from 1903 to 1928

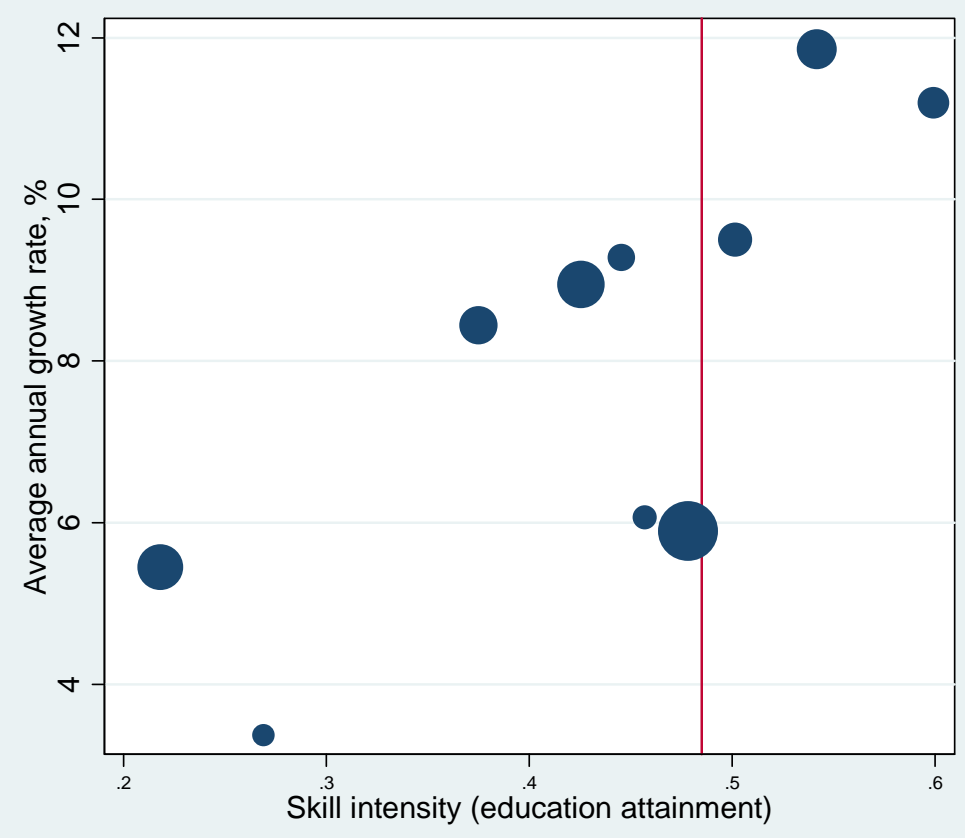

Source: Authors' calculation as described in the text. Skill intensity based on data from the 1940 US census. 
Figure 8. Skill Intensity and the Growth Rate of Exports from 1903 to 1928

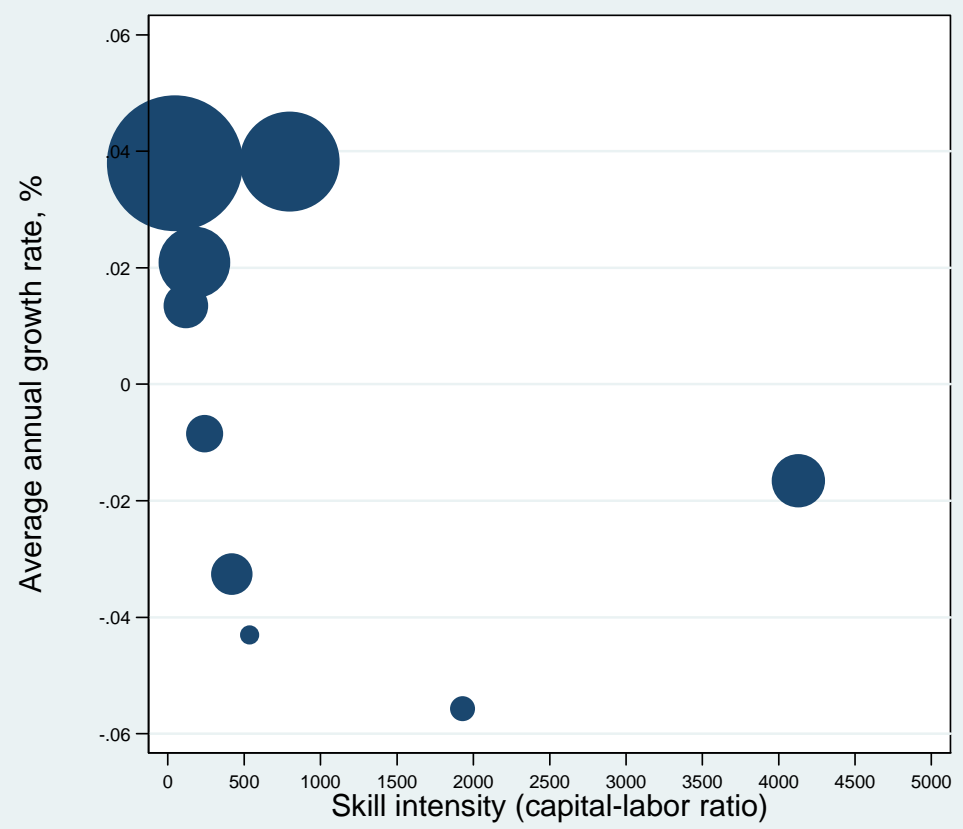

Source: Authors' calculation as described in the text. Skill intensity based on data from the 1928 Shanghai Survey

Figure 9. Skill Intensity and the Growth Rate of Imports from 1903 to 1928

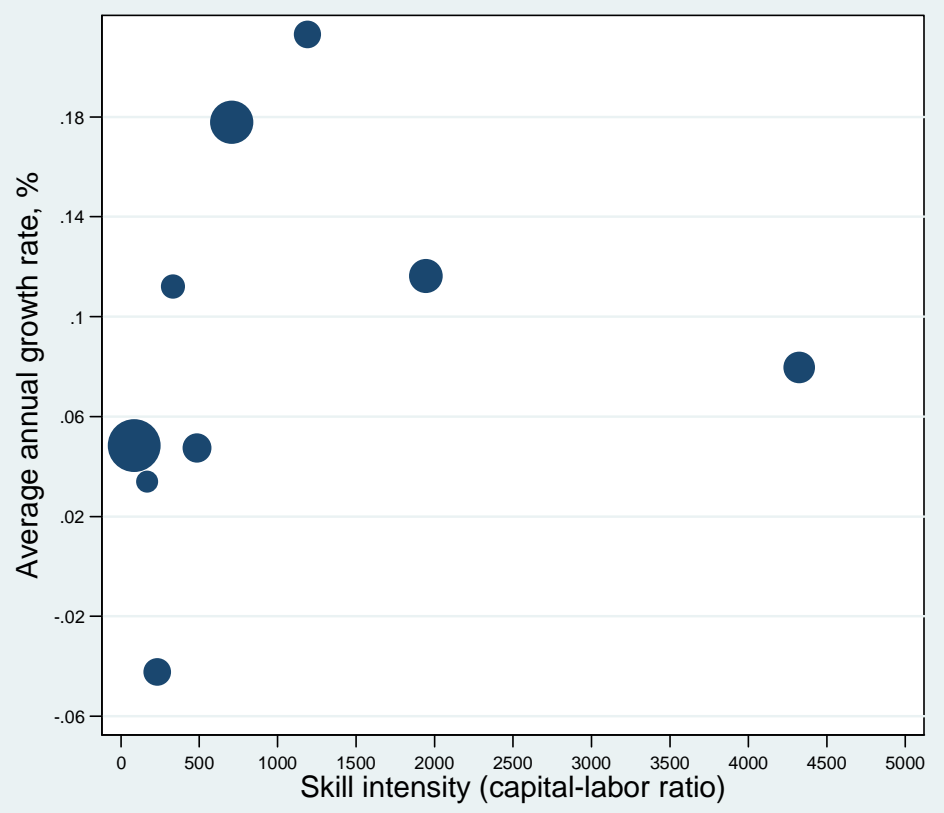

Source: Authors' calculation as described in the text. Skill intensity based on data from the 1928 Shanghai Survey. 
Figure 10. Terms of Trade for China, 1903 to 1928

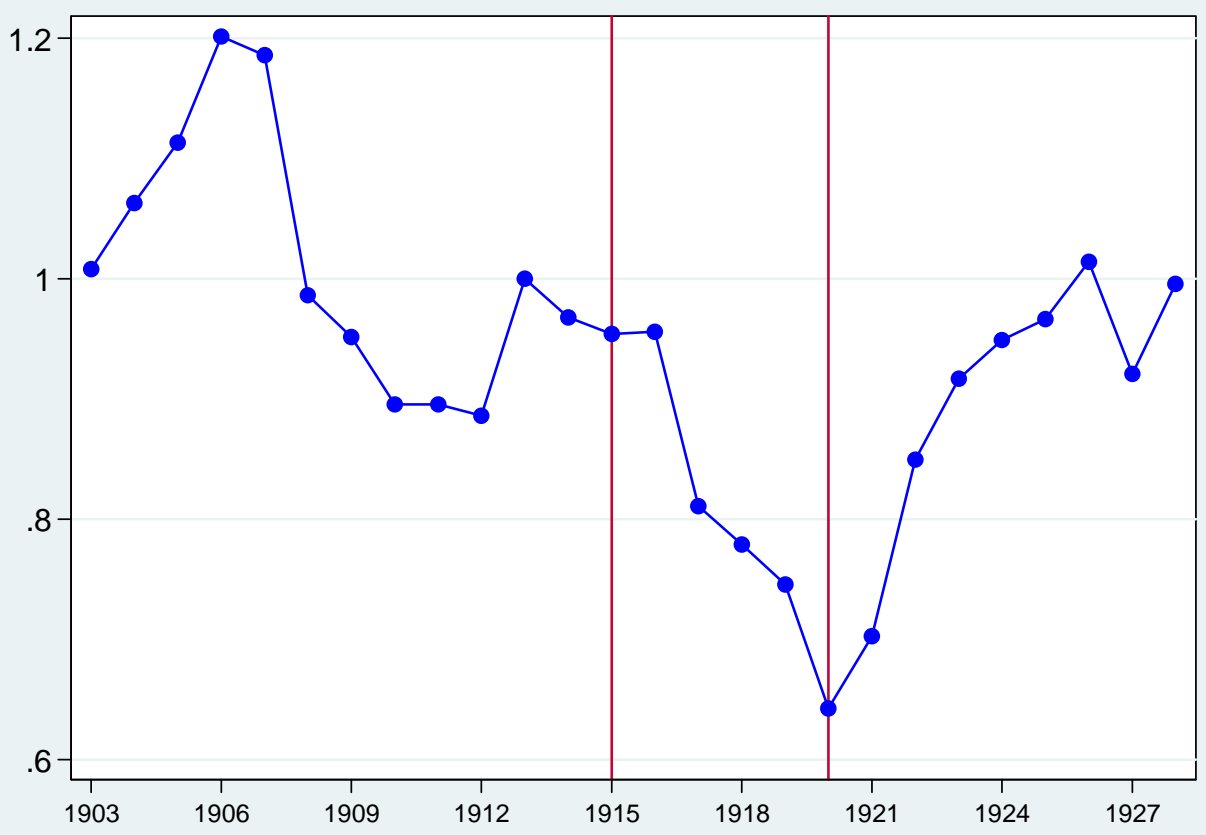

Source: Authors calculations based on underlying trade data described in text. We divide F.O.B export prices by C.I.F. import prices to derive terms of trade. 
Figure 11. Annual Percentage Growth Rates for Prices of Major Export Commodities

Panel A. 1903 to 1928

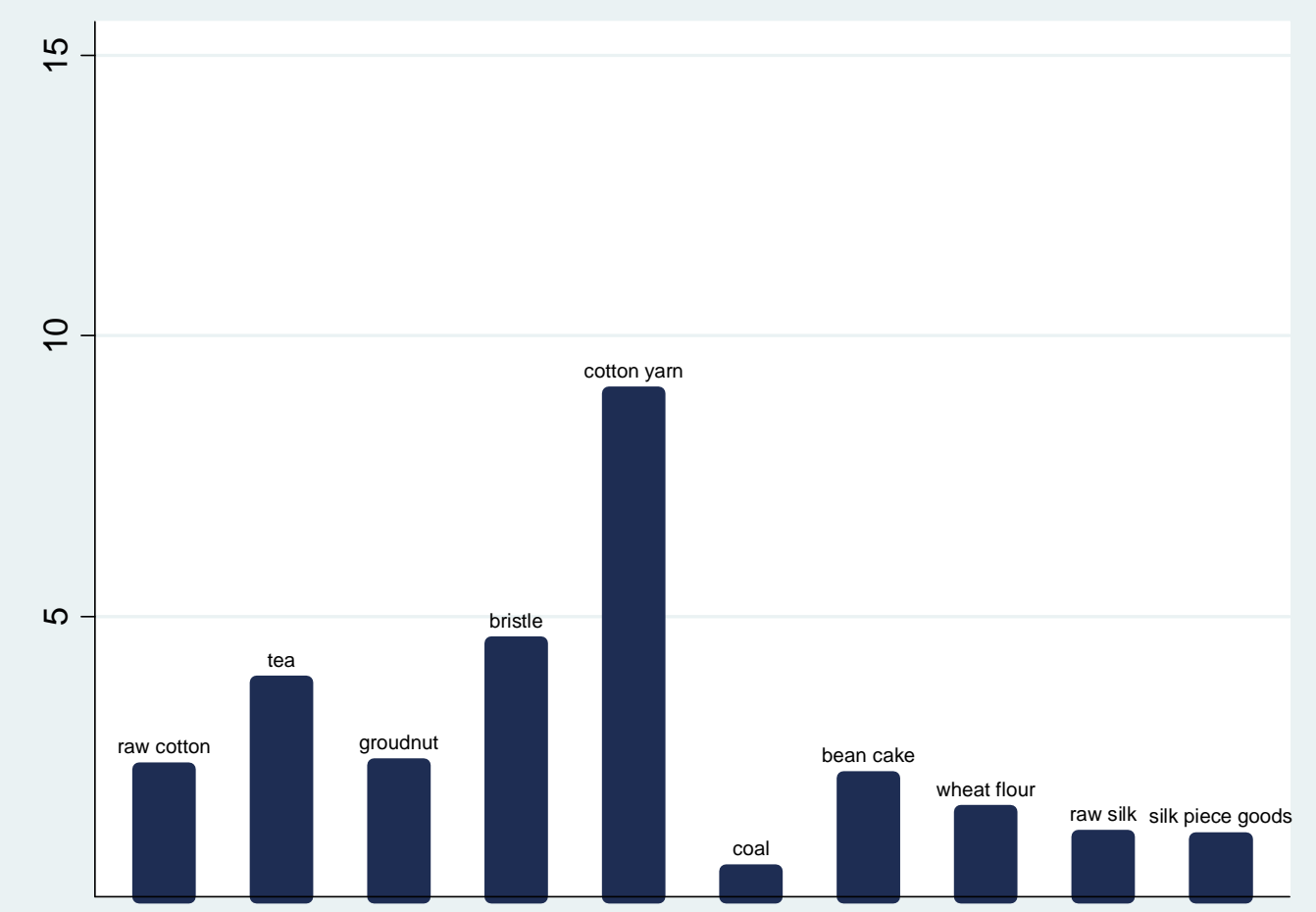

Panel B. 1914 to 1928

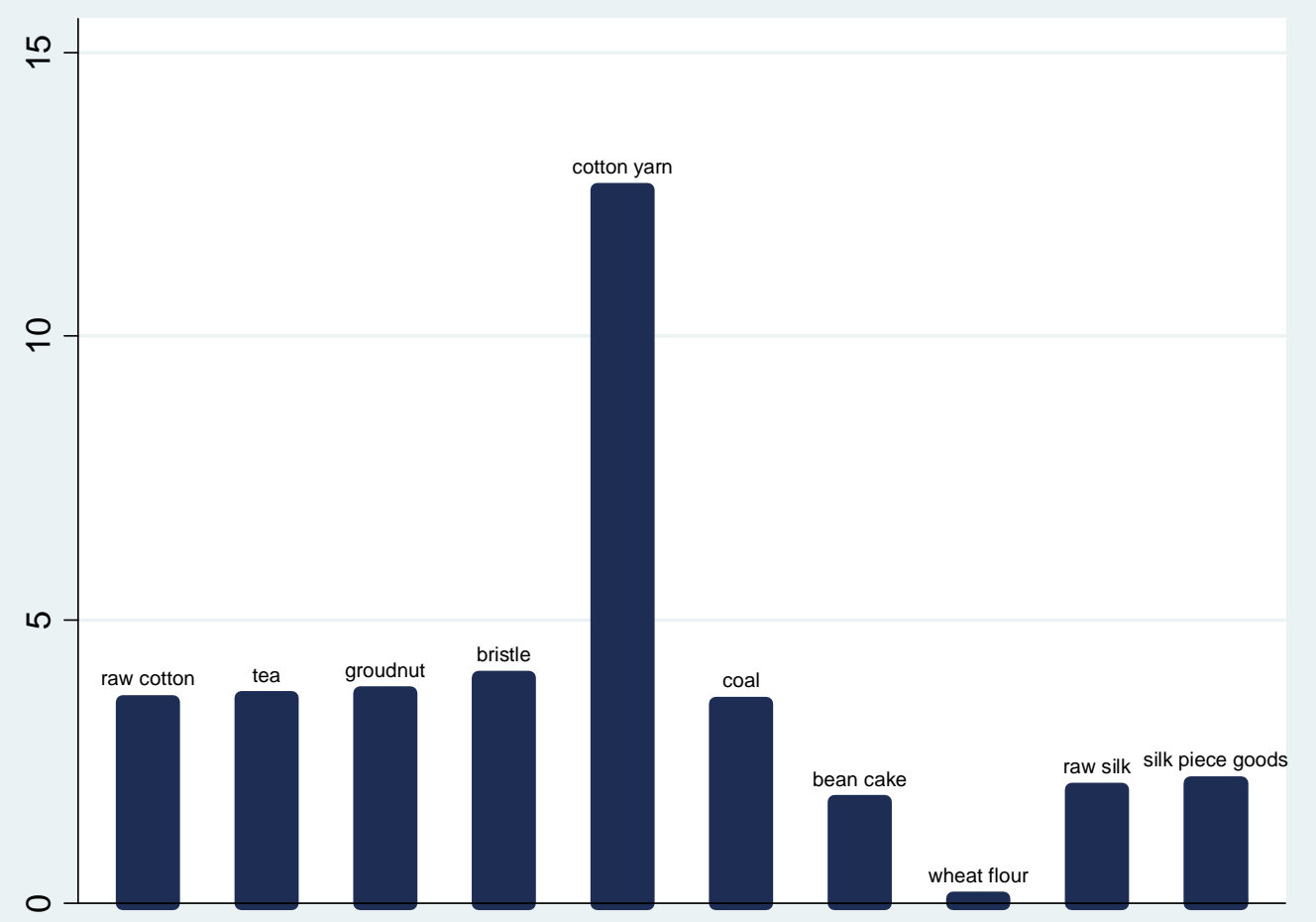

Source: Authors' calculations using data from the CMC’s annual trade publications 
Figure 12. Export Price of Cotton Yarn

Index: $1913=100$

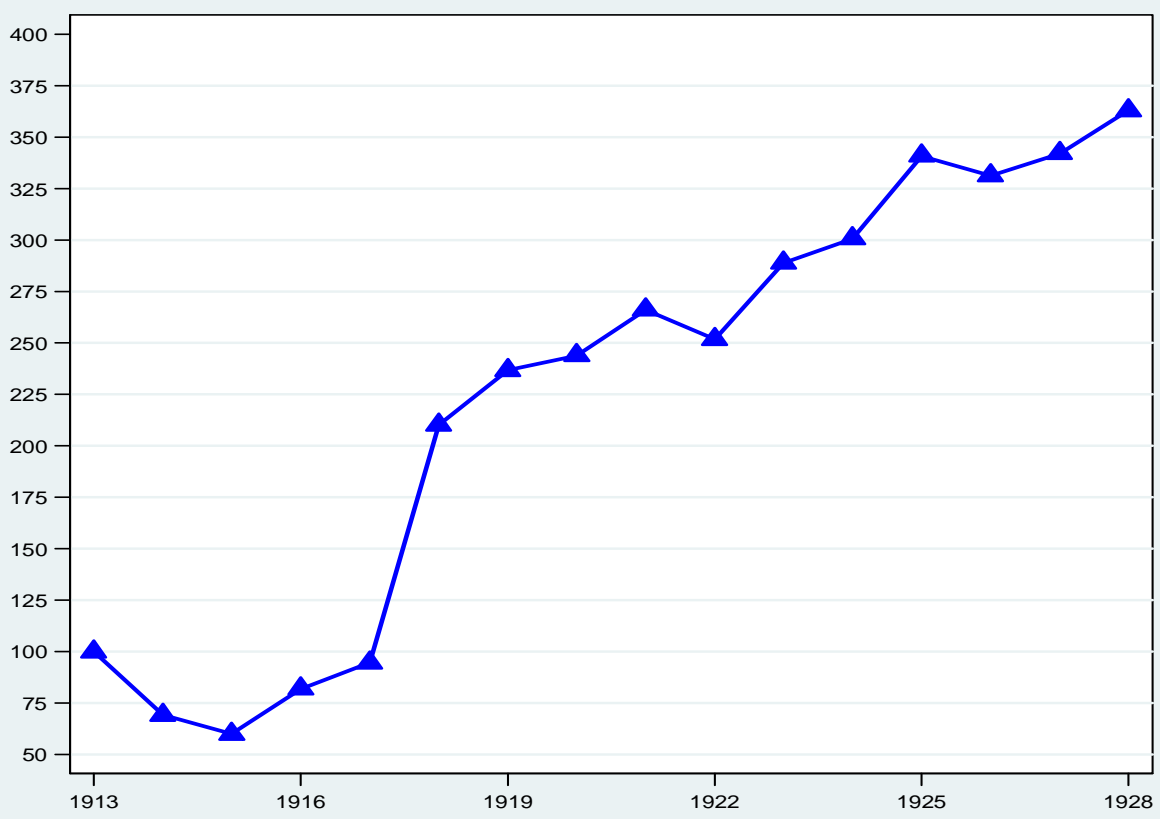

Source: Unit values based on authors' calculations using CMC annual trade publications.

Figure 13. Simulation of the Skill Premium

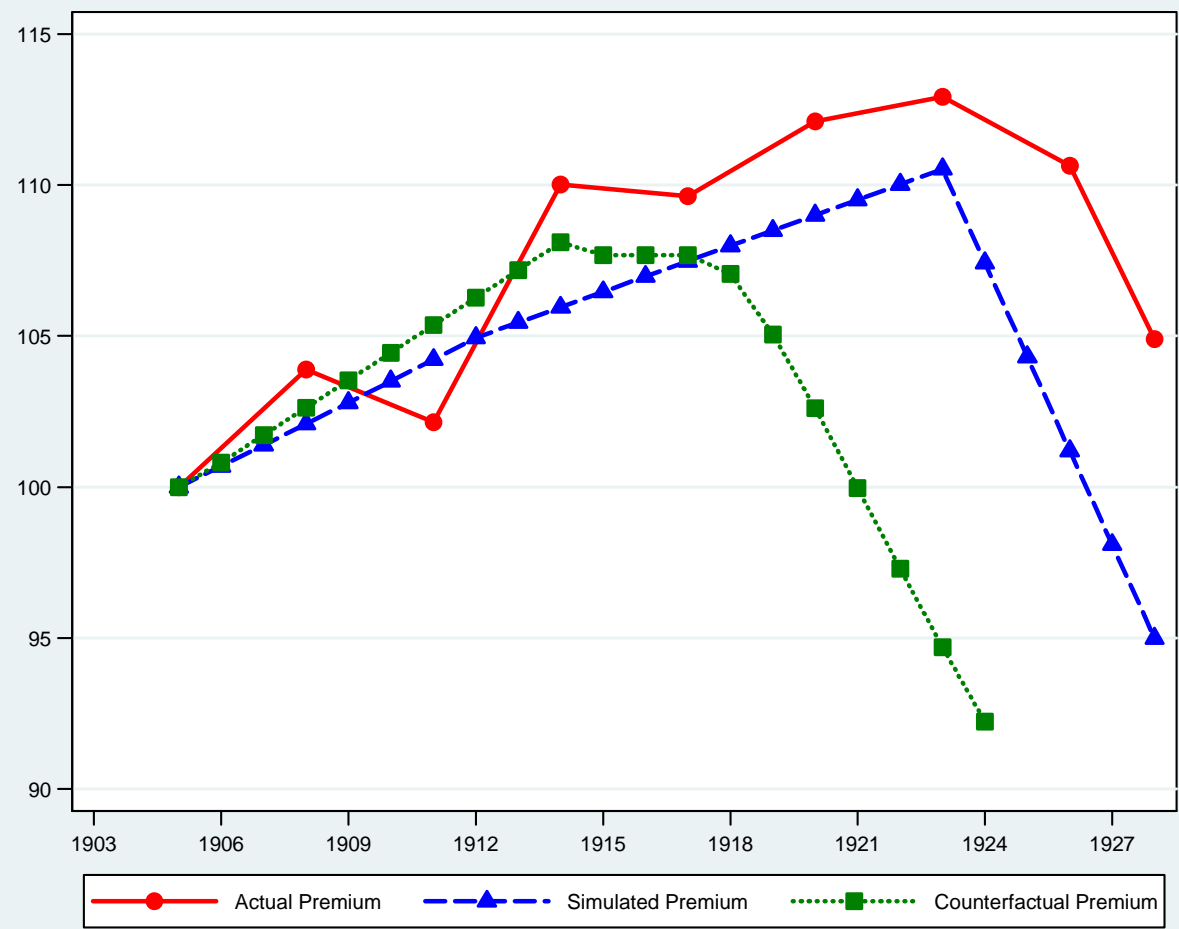

Notes: "Counterfactual” shows a simulation of the model using an alternative terms of trade series where World War I's temporary effects on import prices are removed. 


\section{Appendix 1. Data on the Skill Premium}

Yan (2008) constructs detailed estimates of real wages and the skill premium for China between 1858 and 1936. 44,600 wage observations are collected from China Maritime Customs (“CMC” hereafter) archives, which were recorded by the customs stations in nearly fifty Chinese cities. Roughly half of the archives pertain to labor, which include surveys of local wages and standards of living, CMC wage scales, and most importantly, the "service lists" - that is, the individual personnel records of CMC employees. In each year the service lists recorded each employee's name, home town, year of joining the service, year of being promoted, year of transfer to the current customhouse, rank, and monthly salary. Hedonic regression methods are used to estimate nominal wages for both unskilled and skilled workers. Yan (2008) also constructs group-specific cost of living indices from price data and household budget information contained in CMC trade statistics and surveys. Deflating the nominal wage series of the unskilled and skilled labor by the respective cost of living indices yields the real wage series. Dividing the skilled wage series by the unskilled wage series results in the skill premium as plotted in Figure 2. 


\section{Appendix 2. Measures of Skill Intensity}

Table A1. Ranking of Industries by Educational Attainment

\begin{tabular}{|c|c|c|}
\hline IND1950 & Industry & $\begin{array}{l}\text { Fraction of Skilled } \\
\text { Employees }\end{array}$ \\
\hline 377 & Aircraft and parts & 0.72 \\
\hline 459 & Printing, publishing, and allied industries & 0.68 \\
\hline 357 & Office and store machines & 0.64 \\
\hline 386 & Professional equipment & 0.62 \\
\hline 367 & Electrical machinery, equipment and supplies & 0.62 \\
\hline 476 & Petroleum refining & 0.59 \\
\hline 468 & Paints, varnishes, and related products & 0.58 \\
\hline 458 & Misc paper and pulp products & 0.57 \\
\hline 407 & Dairy products & 0.57 \\
\hline 346 & Fabricated steel products & 0.55 \\
\hline 478 & Rubber products & 0.54 \\
\hline 226 & Crude petroleum and natural gas extraction & 0.54 \\
\hline 466 & Synthetic fibers & 0.54 \\
\hline 358 & Misc machinery & 0.54 \\
\hline 469 & Misc chemicals and allied products & 0.53 \\
\hline 356 & Agricultural machinery and tractors & 0.53 \\
\hline 418 & Beverage industries & 0.52 \\
\hline 388 & Watches, clocks, and clockwork-operated devices & 0.52 \\
\hline 409 & Grain-mill products & 0.51 \\
\hline 416 & Bakery products & 0.51 \\
\hline 449 & Misc fabricated textile products & 0.49 \\
\hline 376 & Motor vehicles and motor vehicle equipment & 0.49 \\
\hline 316 & Glass and glass products & 0.48 \\
\hline 338 & Primary nonferrous industries & 0.48 \\
\hline 436 & Knitting mills & 0.48 \\
\hline 457 & Paperboard containers and boxes & 0.47 \\
\hline 426 & Not specified food industries & 0.47 \\
\hline 456 & Pulp, paper, and paper-board mills & 0.47 \\
\hline 417 & Confectionary and related products & 0.47 \\
\hline 406 & Meat products & 0.46 \\
\hline
\end{tabular}

Note: Traded goods were classified into industries using the IND1950 described in the text. Educational attainment is derived using 1940 US census. Please see the text for details. 
Table A1. Ranking of Industries by Educational Attainment (continued)

\begin{tabular}{|c|c|c|}
\hline IND1950 & Industry & $\begin{array}{l}\text { Fraction of } \\
\text { Skilled } \\
\text { Employees }\end{array}$ \\
\hline 489 & Leather products, except footwear & 0.46 \\
\hline 378 & Ship and boat building and repairing & 0.45 \\
\hline 487 & Leather: tanned, curried, and finished & 0.45 \\
\hline 337 & Other primary iron and steel industries & 0.44 \\
\hline 477 & Misc petroleum and coal products & 0.44 \\
\hline 379 & Railroad and misc transportation equipment & 0.44 \\
\hline 488 & Footwear, except rubber & 0.43 \\
\hline 326 & Misc nonmetallic mineral and stone products & 0.43 \\
\hline 408 & Canning and preserving fruits, vegetables, and seafood & 0.43 \\
\hline 319 & Pottery and related prods & 0.43 \\
\hline 446 & Misc textile mill products & 0.42 \\
\hline 437 & Dyeing and finishing textiles, except knit goods & 0.42 \\
\hline 308 & Misc wood products & 0.42 \\
\hline 309 & Furniture and fixtures & 0.42 \\
\hline 348 & Not specified metal industries & 0.41 \\
\hline 206 & Metal mining & 0.41 \\
\hline 336 & Blast furnaces, steel works, and rolling mills & 0.4 \\
\hline 317 & Cement, concrete, gypsum and plaster products & 0.4 \\
\hline 448 & Apparel and accessories & 0.39 \\
\hline 116 & Forestry & 0.37 \\
\hline 438 & Carpets, rugs, and other floor coverings & 0.35 \\
\hline 318 & Structural clay products & 0.33 \\
\hline 439 & Yarn, thread, and fabric & 0.32 \\
\hline 246 & Construction & 0.31 \\
\hline 429 & Tobacco manufactures & 0.3 \\
\hline 307 & Sawmills, planting mills, and mill work & 0.28 \\
\hline 236 & Nonmetallic mining and quarrying, except fuel & 0.27 \\
\hline 126 & Fisheries & 0.26 \\
\hline 105 & Agriculture & 0.22 \\
\hline 306 & Logging & 0.22 \\
\hline 216 & Coal mining & 0.2 \\
\hline
\end{tabular}


Table A2. Ranking of Industries by Log Wages

\begin{tabular}{|c|c|c|}
\hline IND1950 & Industry & Log Wage \\
\hline 476 & Petroleum refining & 3.207 \\
\hline 226 & Crude petroleum and natural gas extraction & 3.127 \\
\hline 468 & Paints, varnishes, and related products & 3.126 \\
\hline 378 & Ship and boat building and repairing & 3.124 \\
\hline 459 & Printing, publishing, and allied industries & 3.124 \\
\hline 357 & Office and store machines & 3.122 \\
\hline 358 & Misc machinery & 3.109 \\
\hline 418 & Beverage industries & 3.1 \\
\hline 469 & Misc chemicals and allied products & 3.099 \\
\hline 376 & Motor vehicles and motor vehicle equipment & 3.098 \\
\hline 367 & Electrical machinery, equipment and supplies & 3.095 \\
\hline 386 & Professional equipment & 3.092 \\
\hline 478 & Rubber products & 3.092 \\
\hline 336 & Blast furnaces, steel works, and rolling mills & 3.091 \\
\hline 356 & Agricultural machinery and tractors & 3.078 \\
\hline 346 & Fabricated steel products & 3.075 \\
\hline 406 & Meat products & 3.07 \\
\hline 377 & Aircraft and parts & 3.067 \\
\hline 407 & Dairy products & 3.06 \\
\hline 337 & Other primary iron and steel industries & 3.055 \\
\hline 338 & Primary nonferrous industries & 3.055 \\
\hline 456 & Pulp, paper, and paper-board mills & 3.048 \\
\hline 316 & Glass and glass products & 3.047 \\
\hline 348 & Not specified metal industries & 3.045 \\
\hline 317 & Cement, concrete, gypsum and plaster products & 3.036 \\
\hline 416 & Bakery products & 3.032 \\
\hline 426 & Not specified food industries & 3.031 \\
\hline 379 & Railroad and misc transportation equipment & 3.03 \\
\hline 487 & Leather: tanned, curried, and finished & 3.028 \\
\hline 326 & Misc nonmetallic mineral and stone products & 3.024 \\
\hline 466 & Synthetic fibers & 3.023 \\
\hline 388 & Watches, clocks, and clockwork-operated devices & 3.02 \\
\hline
\end{tabular}

Note: Traded goods were classified into industries using the IND1950 described in the text. Log wage is derived using 1940 US census. Please see the text for details. 
Table A2. Ranking of Industries by Log Wages (continued)

\begin{tabular}{clc}
\hline \hline IND1950 & & \multicolumn{1}{c}{ Industry } \\
\hline 477 & Misc petroleum and coal products & Log Wage \\
409 & Grain-mill products & 3.017 \\
458 & Misc paper and pulp products & 3.011 \\
206 & Metal mining & 3.007 \\
\hline 319 & Pottery and related products & 3.006 \\
446 & Misc textile mill products & 2.986 \\
438 & Carpets, rugs, and other floor coverings & 2.984 \\
318 & Structural clay products & 2.973 \\
457 & Paperboard containers and boxes & 2.954 \\
309 & Furniture and fixtures & 2.953 \\
437 & Dyeing and finishing textiles, except knit goods & 2.943 \\
308 & Misc wood products & 2.937 \\
489 & Leather products, except footwear & 2.931 \\
417 & Confectionary and related products & 2.913 \\
216 & Coal mining & 2.905 \\
436 & Knitting mills & 2.9 \\
488 & Footwear, except rubber & 2.897 \\
429 & Tobacco manufactures & 2.886 \\
236 & Nonmetallic mining and quarrying, except fuel & 2.865 \\
439 & Yarn, thread, and fabric & 2.85 \\
408 & Canning and preserving fruits, vegetables, and seafood & 2.847 \\
307 & Sawmills, planting mills, and mill work & 2.827 \\
448 & Apparel and accessories & 2.815 \\
246 & Construction & 2.812 \\
449 & Misc fabricated textile products & 2.796 \\
306 & Logging & 2.79 \\
116 & Forestry & 2.703 \\
126 & Fisheries & 2.682 \\
105 & Agriculture & 2.666 \\
\hline \hline & & 2.095 \\
\hline
\end{tabular}




\section{Appendix 3}

Table A3. Ranking of Industries by the 1928 Shanghai Survey

\begin{tabular}{|c|c|c|}
\hline Industry Code & Industry Name & $\begin{array}{l}\text { Capital-Labor Ratio } \\
\text { Unit: Chinese Yuan per worker }\end{array}$ \\
\hline 93 & Electric and water works & 10628.86 \\
\hline 46 & Condiments & 5169.01 \\
\hline 26 & Medicine & 4356.16 \\
\hline 47 & Cigars and cigarettes & 4298.39 \\
\hline 71 & Metal products & 3746.26 \\
\hline 27 & Manufacture of paper & 3118.92 \\
\hline 31 & Manufacture of varnish & 2099.24 \\
\hline 29 & Manufacture of enameled ware & 2009.51 \\
\hline 73 & Musical instruments and toys & 1810.9 \\
\hline 28 & Match making & 1668.87 \\
\hline 91 & Building material & 1582.64 \\
\hline 25 & Glassware & 1342.49 \\
\hline 63 & Founding & 1163.01 \\
\hline 86 & Clothing & 1142.16 \\
\hline 92 & Coal briquettes & 1140.46 \\
\hline 23 & Cosmetics & 977.14 \\
\hline 74 & Scientific apparatus & 955.95 \\
\hline 41 & Wheat flour mills & 900.91 \\
\hline 43 & Oil mills & 881.55 \\
\hline 45 & Frozen egg products & 782.83 \\
\hline 32 & Other chemical & 739.37 \\
\hline 51 & Printing & 727.67 \\
\hline 81 & Hats & 722.83 \\
\hline 75 & Other tools and instruments & 641.51 \\
\hline 21 & Dyeing and printing of textiles & 618.92 \\
\hline 48 & Candies and canned food & 598 \\
\hline 49 & Other food & 501.96 \\
\hline
\end{tabular}

Note: Traded goods were classified into industries using the 1928 Shanghai survey data described in the text. Capital-labor ratio is derived using this survey too. Please see the text for details. 
Table A3. Ranking of Industries by the 1928 Shanghai Survey (continued)

\begin{tabular}{|c|c|c|}
\hline Industry Code & Industry Name & Capital-Labor Ratio \\
\hline 16 & Knitted goods & 488.5 \\
\hline 17 & Other textile & 477.26 \\
\hline 62 & Manufacture of electrical instruments & 396.32 \\
\hline 94 & Trimmings and ribbons & 387.11 \\
\hline 82 & Umbrellas & 379.27 \\
\hline 11 & Cotton spinning & 357.99 \\
\hline 97 & Other miscellaneous industries & 344.68 \\
\hline 83 & Brushes & 325.1 \\
\hline 84 & Writing outfit & 294.87 \\
\hline 12 & Cotton weaving & 277.37 \\
\hline 15 & Wool weaving & 258.09 \\
\hline 22 & Leather manufacturing & 241.06 \\
\hline 64 & Shipbuilding & 240.55 \\
\hline 14 & Silk weaving & 204.25 \\
\hline 96 & Cotton ginning & 203.19 \\
\hline 85 & Spectacles & 188.54 \\
\hline 72 & Wooden, rattan, and bamboo articles & 146.68 \\
\hline 44 & Soda water and other soft drinks & 129.78 \\
\hline 24 & Soap and candles & 127.62 \\
\hline 87 & Other daily necessities & 114.09 \\
\hline 61 & Manufacture and repairing of machines & 81.27 \\
\hline 42 & Rice mills & 59.77 \\
\hline 13 & Silk reeling & 47.69 \\
\hline 95 & Cartons & 38.1 \\
\hline
\end{tabular}


Appendix Figure 1. Export and Import Shares by Skill Intensity, 1903-1928

Panel A: Unskilled trade

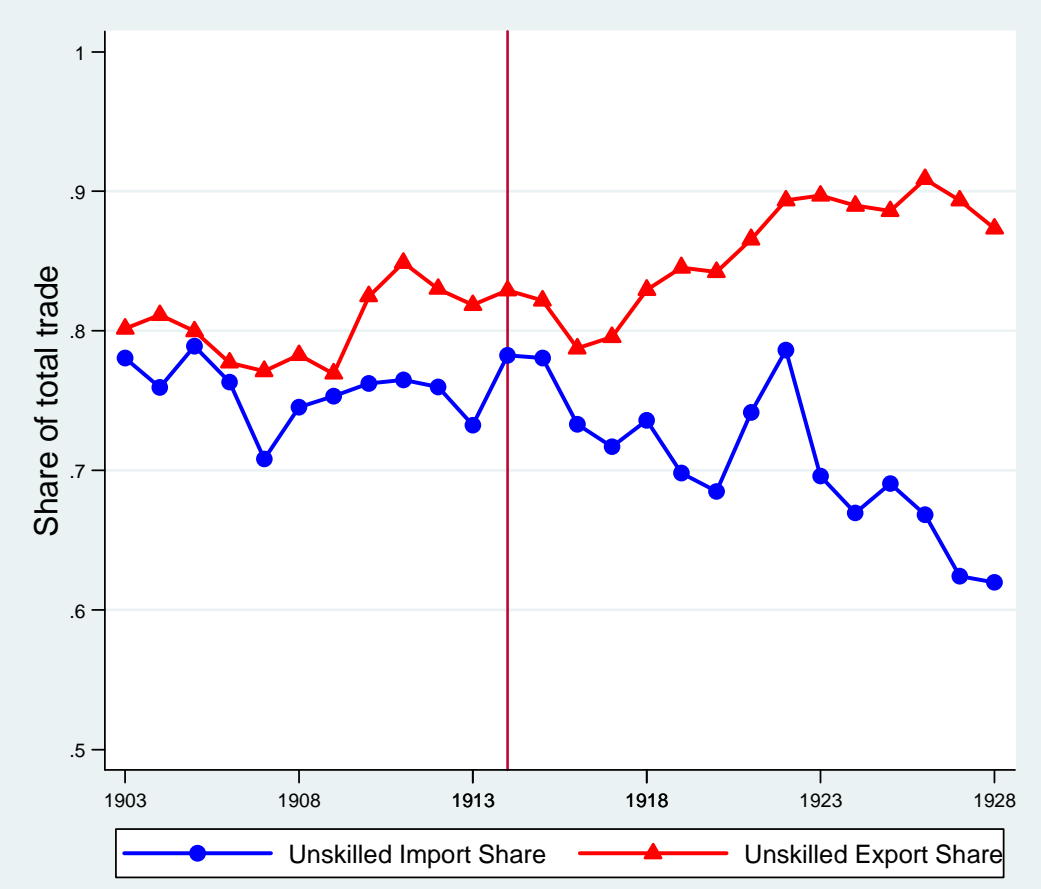

Panel B: Skilled Trade

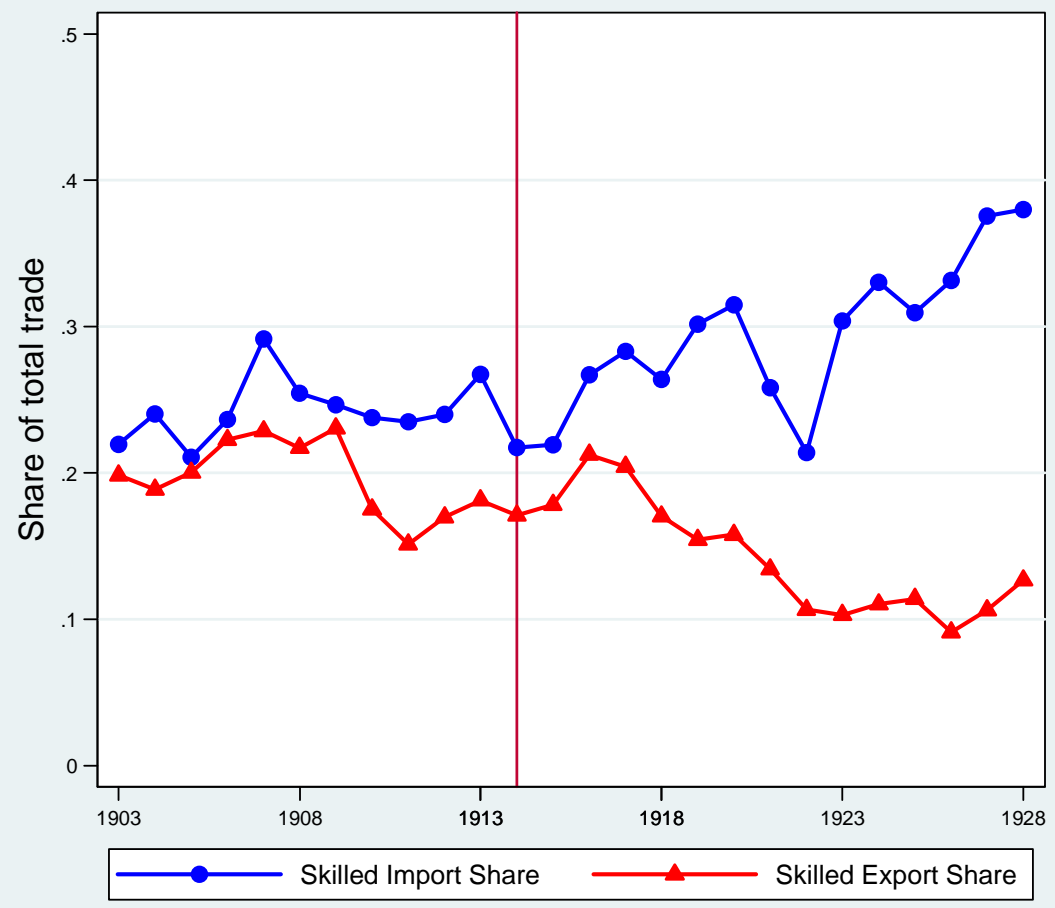

Notes: Skill intensity is classified by average wages using data from the 1940 US census. See the text for further details. 
Appendix Figure 2. Value of Exports and Imports by Skill Intensity, 1903 and 1928

(Thousands of Haikwan Tael)

Panel A: 1903

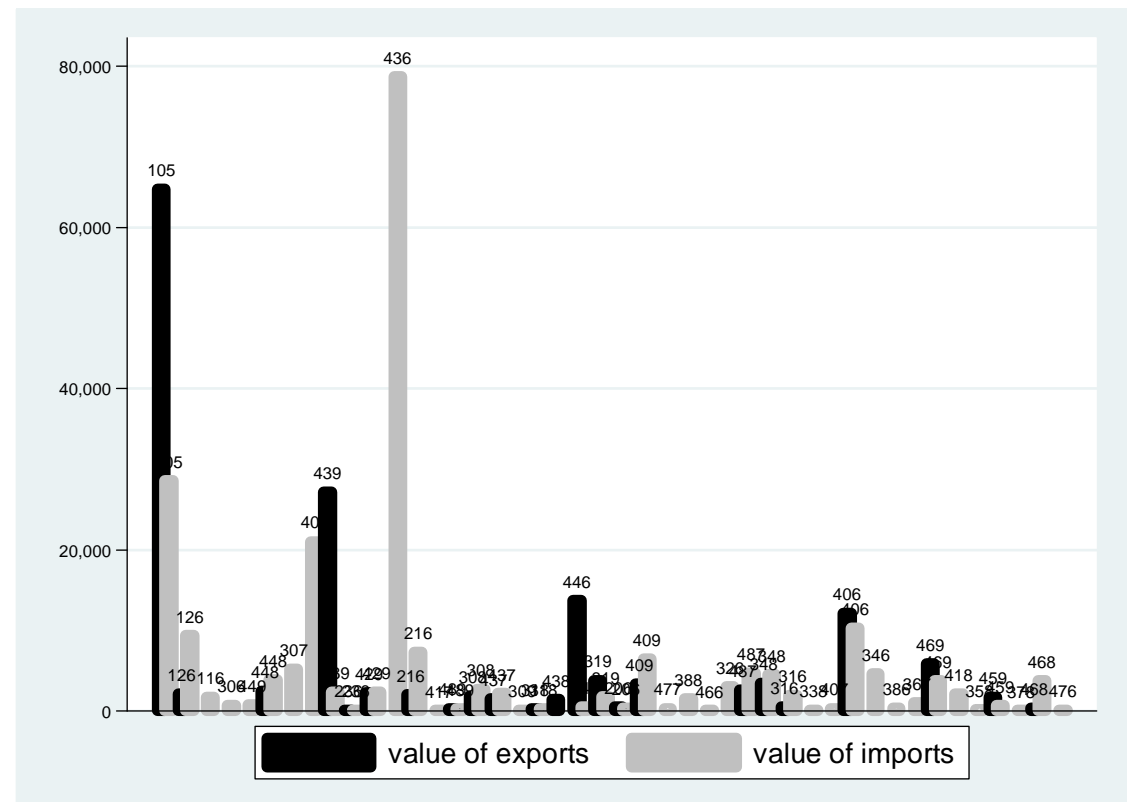

Panel B: 1928

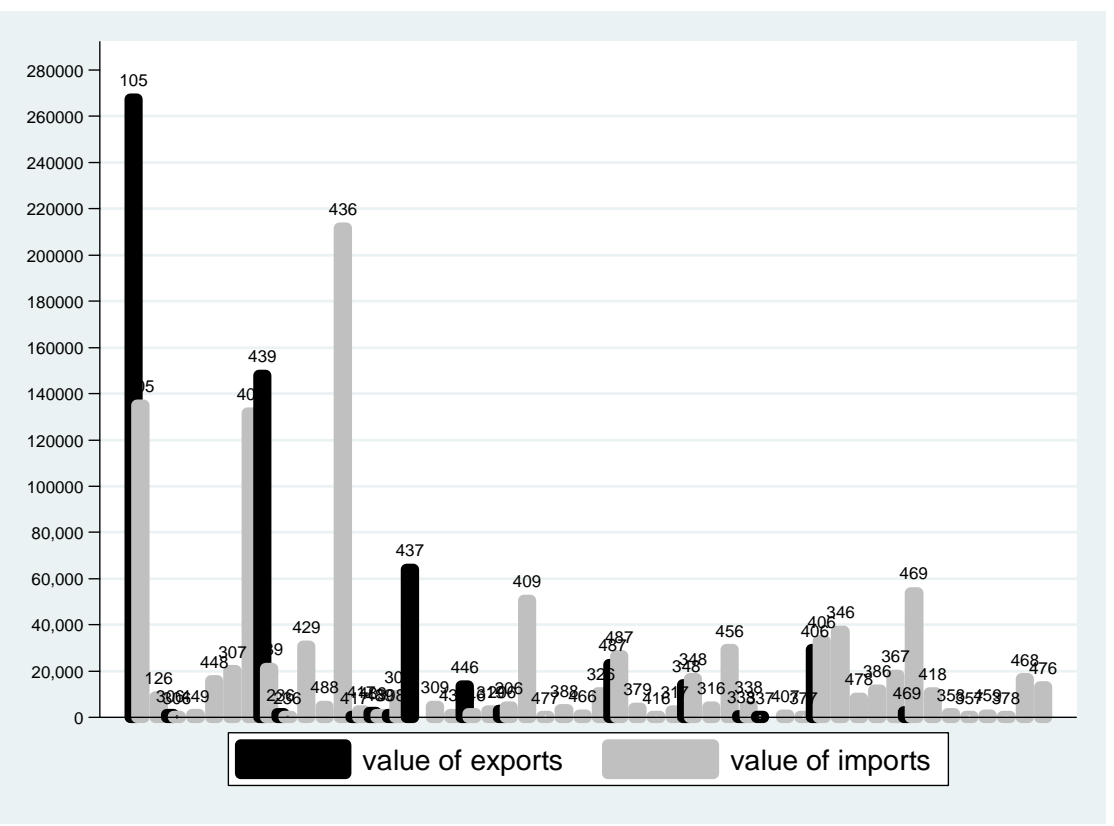

Source: Skill intensity is classified by wages as described in the text. Numbers on individual bars correspond to industry codes listed in Appendix Tables A1 and A2. 